\title{
Proteomics Recapitulates Ovarian Proteins Relevant to Puberty and Fertility in Brahman Heifers (Bos indicus L.)
}

\author{
Muhammad S. Tahir ${ }^{1}$, Loan T. Nguyen ${ }^{2}$ (D) Benjamin L. Schulz ${ }^{1}$, Gry A. Boe-Hansen ${ }^{3}$, \\ Milton G. Thomas ${ }^{4}$, Stephen S. Moore ${ }^{2}$, Li Yieng Lau ${ }^{1}$ and Marina R. S. Fortes ${ }^{1, *}$ \\ 1 School of Chemistry and Molecular Bioscience, University of Queensland, Brisbane 4072, \\ Queensland, Australia; m.tahir@uqconnect.edu.au (M.S.T.); b.schulz@uq.edu.au (B.L.S.); \\ liyieng.lau@uq.net.au (L.Y.L.) \\ 2 Queensland Alliance for Agriculture and Food Innovation, University of Queensland, Brisbane 4072, \\ Queensland, Australia; t.nguyen3@uq.edu.au (L.T.N.); s.moore3@uq.edu.au (S.S.M.) \\ 3 School of Veterinary Sciences, University of Queensland, Brisbane 4343, \\ Queensland, Australia; g.boehansen@uq.edu.au \\ 4 Department of Animal Science, Colorado State University, Fort Collins, CO 80523, \\ USA; milt.thomas@colostate.edu \\ * Correspondence: m.fortes@uq.edu.au
}

Received: 22 October 2019; Accepted: 6 November 2019; Published: 12 November 2019

check for updates

\begin{abstract}
High fertility and early puberty in Bos indicus heifers are desirable and genetically correlated traits in beef production. The hypothalamus-pituitary-ovarian (HPO) axis synthesizes steroid hormones, which contribute to the shift from the pre-pubertal state into the post-pubertal state and influence subsequent fertility. Understanding variations in abundance of proteins that govern steroid synthesis and ovarian signaling pathways remains crucial to understanding puberty and fertility. We used whole ovaries of six pre-pubertal and six post-pubertal Brahman heifers to conduct differential abundance analyses of protein profiles between the two physiological states. Extracted proteins were digested into peptides followed by identification and quantification with massspectrometry (MS) by sequential window acquisition of all instances of theoretical fragment ion mass spectrometry (SWATH-MS). MS and statistical analysis identified 566 significantly differentially abundant (DA) proteins (adjusted $p<0.05$ ), which were then analyzed for gene ontology and pathway enrichment. Our data indicated an up-regulation of steroidogenic proteins contributing to progesterone synthesis at luteal phase post-puberty. Proteins related to progesterone signaling, TGF- $\beta$, retinoic acid, extracellular matrix, cytoskeleton, and pleiotrophin signaling were DA in this study. The DA proteins probably relate to the formation and function of the corpus luteum, which is only present after ovulation, post-puberty. Some DA proteins might also be related to granulosa cells signaling, which regulates oocyte maturation or arrest in ovaries prior to ovulation. Ten DA proteins were coded by genes previously associated with reproductive traits according to the animal quantitative trait loci (QTL) database. In conclusion, the DA proteins and their pathways were related to ovarian activity in Bos indicus cattle. The genes that code for these proteins may explain some known QTLs and could be targeted in future genetic studies.
\end{abstract}

Keywords: Bos indicus; ovary; puberty; steroidogenesis; progesterone signaling; oocyte maturation; corpus luteum; massspectrometry 


\section{Introduction}

Early puberty, pregnancy maintenance, and successful calving contribute to the life-time reproductive performance of cows [1]. Bos indicus cattle are tropically adapted but come across fertility problems in early reproductive age which include delayed puberty as compared to Bos taurus and pregnancy-related losses [2]. Age at puberty, as measured by observance of the first corpus luteum (CL) and age at first calving (AFC) are early in life reproductive traits that are crucial to heifers' fertility [3-8]. Previous genome wide association studies have indicated the polygenic nature of these traits $[9,10]$. Fertility-related traits are expressed as a consequence of puberty, so it is important to investigate the biology of puberty as it impacts on subsequent fertility.

Puberty begins with widespread changes in the hypothalamus-pituitary-ovarian (HPO) axis and plasma hormonal profiles [11,12]. Ovaries play a crucial role in the regulation of the HPO axis by negative and positive feedback mechanisms related to the gonadostat theory and the onset of puberty [13]. According to the gonadostat theory, ovarian estrogen imparts its negative feedback on the hypothalamus to suppress frequency of gonadotrophic releasing hormone (GnRH) pulses, which suppresses luteinizing hormone (LH) secretion from the pituitary in pre-pubertal life [14]. At puberty, estrogen through its positive feedback increases the pulse frequency of GnRH from hypothalamus, which releases LH and follicle stimulating hormone (FSH) from the pituitary, leading to pre-ovulatory follicle development and ovulation [11,13]. Ovarian estrogen feedback mechanisms are important in the complex systemic changes that control puberty.

Steroid synthesis in ovaries is dependent on the interconnected functioning of theca and granulosa cells in response to FSH and LH hormones. In bovine ovaries, theca cells synthesize androgen while follicular cells synthesize estrogen [15]. LH is the hormone signal for ovulation and therefore controls the luteinization of theca and granulosa cells that results in synthesis of progesterone by up-regulation of P450 enzymes CYP11A and HSD3 $\beta 1$ and down-regulation of P450 enzyme CYP17A1 and aromatase (CYP19A1) [16]. Progesterone is involved in oocyte quality and embryo development in cows [17] and its post-ovulatory rise, produced by the CL, is necessary for normal maintenance of pregnancy, meaning it contributes to heifer fertility [1].

The onset of puberty corresponds to the maturation of oocytes, which are arrested in the diplotene stage of meiosis prophase-1 in fetal life [18]. Ovarian granulosa and theca cells are crucial to oocyte maturation [19]. Oocyte maturation impacts on subsequent fertility, although its mechanisms are not entirely clear in cattle. Multiple studies have suggestedthe role of gonadotropins (LH/FSH) in inducing bovine oocyte meiotic maturation with probable dependence on paracrine functioning of growth factors (TGF- $\beta$, TGF- $\alpha$, EGF, IGF-1, and activin) from theca and granulosa cells [20-22]. Progesterone also plays role in oocyte maturation $[23,24]$. Progesterone signals to rapid induction of oocyte maturation by increased intracellular $\mathrm{Ca}^{2+}$, inactivating the adenylate cyclase PKA system, initiating the Mos/MEK/MAPK cascade, and activating Cdk1/Cyclin-B, as reported in Xenopus frogs [25]. Granulosa cells are important for oocyte maturation, fertilization, and embryo development [26]. The interplay between granulosa cells and progesterone signaling occurs at two different stages of the estrous cycle to execute two important functions: (1) oocyte maturation just before ovulation and (2) CL activity after conversion of granulosa cells to luteal cells that will support subsequent pregnancy.

The physiological functions of tissues depend on the regulation of protein abundance, affecting biological pathways. The multifaceted phenomenon of puberty, including the production of progesterone in ovaries post-puberty, requires further elucidation that can be achieved with proteomics. Determination of protein differential abundance in ovarian tissues of pre-pubertal and first cycle post-pubertal heifers can be useful to revealing key players controlling the complex mechanisms of CL formation and puberty. Most studies done so far on ovarian functional pathways have addressed a limited number of candidate genes or proteins $[27,28]$. Global gene expression (transcriptomics) in ovaries of pre- and post-pubertal heifers have been reported, with many genes being differentially expressed between these two physiological states [28-30]. Transcriptome and proteome analyses often reveal different aspects of a physiological event [31]. Proteome analyses measure the effectors of 
biological function, i.e., the proteins themselves. A recent study identified neuropeptides that differed between pre- and post-pubertal cows in the hypothalamus and the pituitary [32]. A similar report for ovarian tissue is lacking. The aim of this study was to identify proteins and pathways that are related to the onset of puberty and are important for CL function, and which therefore could play a role in subsequent fertility. To achieve this goal, protein abundance was measured in the ovaries of pre-pubertal and post-pubertal heifers (at the luteal phase).

\section{Materials and Methods}

\subsection{Animal Selection and Sampling}

All experimental procedures were approved by the Animal Ethics Committee of The University of Queensland, Production and Companion Animal Group (certificate number QAAFI/279/12). Twenty Brahman heifers were sourced as weanlings $(<250 \mathrm{~kg})$ from two commercial herds in Queensland, Australia, and managed together at the Gatton Campus facilities of the University of Queensland.

Heifers' ovarian activity was observed using ultrasonography every fortnight for eight consecutive months (HS-2000(VET), Honda Electronics Inc.). When a CL was identified the heifer was deemed post-pubertal and paired randomly with a pre-pubertal heifer (no CL observed) for same-day euthanasia [3]. Euthanasia was planned for approximately 21 days after detection of the first CL, as described before [23]. On euthanasia day, we also measured the size of the largest follicle in each ovary and found that there was no statistical difference between pre- and post-pubertal heifers according to this criterium. The entire ovaries were harvested and preserved by snap freezing in liquid nitrogen and kept at $-80{ }^{\circ} \mathrm{C}$ until protein extraction. We recorded which ovary had the CL for post-pubertal heifers. When thawed, the entire ovaries were pulverized and homogenized using a mortar and pestle and liquid nitrogen to produce a uniform sample for each ovary. Subsequently, aliquots of pulverized tissue of the left and right ovaries of the same heifer were mixed to produce a sample that would represent all ovarian tissue for proteomics. Plasma levels of progesterone were measured to confirm the luteal phase status post-puberty (average $2.0 \pm 0.7 \mathrm{ng} / \mathrm{mL}$ ). The average concentration of progesterone in pre-pubertal heifers was significantly lower $(0.4 \pm 0.2 \mathrm{ng} / \mathrm{mL})$, as has been previously described [29].

\subsection{Proteomics, Mass Spectrometry, and Data Analysis}

Tissue samples from both ovaries were ground in liquid nitrogen so that fragments would represent the entire tissue. Subsequently, the buffer having 6M Guanidine chloride, $50 \mathrm{mM}$ Tris $\mathrm{pH}$ 8 , and $10 \mathrm{Mm}$ DTT was added to lobind tubes containing samples. Samples were then sonicated at $35 \%$ for $10 \mathrm{~s}$, and vortexed at $30{ }^{\circ} \mathrm{C}$ for $1 \mathrm{~h}$ in order to denature the proteins and break disulfide bonds. Then, $25 \mathrm{mM}$ acrylamide was added to the samples and incubated at $30^{\circ} \mathrm{C}$ for $1 \mathrm{~h}$ followed by the addition of $5 \mathrm{mM}$ DTT. A small aliquot of the samples was precipitated by incubation at -20 ${ }^{\circ} \mathrm{C}$ for $16 \mathrm{~h}$ after adding four volumes of 1:1 methanol:acetone to one volume of sample. Afterwards, the proteins were precipitated from aliquot samples by centrifugation at 18,000 rcf for 10 min and the supernatant was discarded. The dried protein pellet was resuspended in $0.1 \%$ SDS. Protein concentration was measured using Nanodrop. Aliquots were further processed by filter-assisted sample preparation, adding $100 \mu \mathrm{g}$ total protein to $10 \mathrm{kDa}$ Cut-off Amicon columns which were then centrifuged at 18,000 rcf for $30 \mathrm{~min}$. Ammonium bicarbonate buffer (50 mM) was added to the Amicon columns and centrifuged again using the same conditions as above. Ammonium bicarbonate buffer $(50 \mathrm{mM})$ and trypsin were then added to the Amicon columns and incubated in a chamber of saturated humidity to prevent evaporation at $37^{\circ} \mathrm{C}$ overnight. The Amicon columns were transferred to new tubes and centrifuged at 18,000 rcf for $30 \mathrm{~min}$, followed by another centrifugation (same conditions) after addition of $0.5 \mathrm{M} \mathrm{NaCl}$. The Amicon columns were discarded and the soluble peptides in the tubes were desalted using C18 ZipTips (Millipore) and resuspended in 9.25\% acetonitrile and $0.1 \%$ formic acid. Desalted peptides were analyzed by liquid chromatography electrospray ionization tandem 
mass spectrometry (LC-ESI-MS/MS) with a TripleTof 5600 instrument as previously described [33], except in this case a 45 min LC gradient was used to separate the peptides. Proteins were identified using information-dependent acquisition analysis of one randomly chosen pre-puberty sample and one randomly chosen post-puberty sample with Protein Pilot v5.0.1 (SCIEX) blasted against a database of proteins downloaded from Uniprot on 28 March 2016, with a total of 43,813 entries assigned to Bos taurus, including 6870 reviewed entries from Swiss-prot and 36,948 unreviewed entries from TrEMBL. Sequential window acquisition of all theoretical mass spectra (SWATH)-MS relative quantitative proteomics [34] data was analyzed with PeakView v2.1 (SCIEX). Statistical analyses were performed using MSstats in $\mathrm{R}$ as previously described [35,36] to identify differentially abundant (DA) proteins with a $p$ value lower than 0.05 adjusted for multiple testing [37].

\subsection{Functional Enrichment and Protein Interaction Analysis}

Enrichment analyses for gene ontology (GO) terms and biological pathways were performed using Uniprot accession identifiers of DA proteins as target lists and the identifiers of all detected proteins as our experimental background list using Database for Annotation, Visualization, and Integrated Discovery (DAVID) [38]. Protein-to-protein interaction analysis of specific proteins was done using Search Tool for the Retrieval of Interacting Genes/Proteins (STRING) [39].

\subsection{Matching DA Proteins to Female Reproduction Quantitative Trait Loci (QTL)}

The genes of DA proteins were also searched for their association with reproductive phenotypes according to the cattle quantitative trait loci database (Cattle QTLdb) [40]. Ovarian function is relevant to female reproduction in general and DA proteins from this study could be linked to CL function as well as puberty. Therefore, we performed an inclusive QTL analysis: we looked for all the female reproduction traits in the QTL database.

\section{Results}

Seven hundred and sixty-nine proteins were identified by LC-ESI-MS/MS detection and ProteinPilot database searching in the ovarian samples of both pre- and post-pubertal animals. Among the identified proteins, 566 were significantly DA when post- and pre-pubertal heifers were compared (Table S1). Among the DA proteins, 321 were up-regulated while 245 were down-regulated in post-pubertal heifers, as compared to pre-pubertal heifers (Figure 1). A high proportion (73\%) of identified proteins were DA.

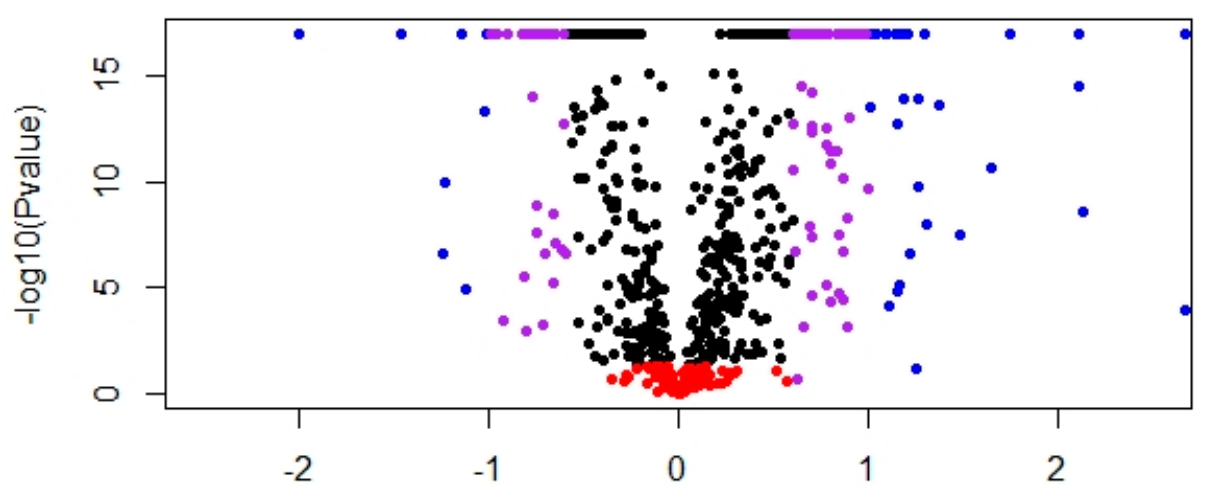

log2FoldChange

Figure 1. Volcano plot of differently abundant (DA) proteins in post-pubertal heifers at the luteal phase versus pre-pubertal Brahman heifers. Red: non-significant (adjusted $p$ value $>0.05$ ). Blue: $\log 2$ fold change $>1$. Purple: $\log 2$ fold change $>0.6$ and $<1$. Black: $\log 2$ fold change $>0$ and $<0.6$. 
In our enrichment analyses using DAVID, no pathways or GO terms were significantly overrepresented in the DA gene list. However, when we analyzed the up- and down-regulated proteins as separated target lists, eight biological pathways terms were enriched: three in the up-regulated list of DA proteins, affecting different metabolic pathways, and five in the down-regulated list of DA proteins, affecting extracellular signaling through extracellular matrix and focal adhesion pathways (Table 1). The genes in each pathway are reported in the Supplementary Material (Table S2).

Table 1. Enriched pathways for up- and down-regulated proteins in post-pubertal heifers at the luteal phase compared to pre-pubertal heifers. Legend: ECM, extracellular matrix.

\begin{tabular}{ccc}
\hline Enriched Pathways & Total Proteins & $\begin{array}{c}\text { DA Benjamini } \\
p \text { Value }\end{array}$ \\
\hline Up-Regulated Proteins & & \\
\hline Ribosome & 35 & $2.8 \times 10^{-5}$ \\
Metabolic pathways & 81 & $9.5 \times 10^{-4}$ \\
Oxidative phosphorylation & 24 & $8.4 \times 10^{-4}$ \\
\hline Down-Regulated Proteins & & \\
\hline Complement and coagulation & 18 & $31.4 \times 10^{-6}$ \\
cascade & 17 & $5.2 \times 10^{-7}$ \\
Systemic lupus erythematosus & 22 & $5.2 \times 10^{-4}$ \\
Focal adhesion & 15 & $7.6 \times 10^{-4}$ \\
ECM receptor interaction & 15 & $4.4 \times 10^{-4}$ \\
Alcoholism & &
\end{tabular}

The 566 DA proteins were classified into 26 functional clusters using DAVID (Table 2 and Table S2). Functional clustering of DA proteins allowed the observation that most of proteins relevant to glycolysis, Tricarboxilic acid (TCA) cycle, pentose phosphate pathway, oxidative phosphorylation, cell redox homeostasis, and glutathione metabolism were up-regulated in post-pubertal heifers compared to pre-pubertal heifers. On the other hand, proteins directly or indirectly related to the extracellular matrix and focal adhesions were down-regulated in post-pubertal heifers (Table 2).

Table 2. Numbers of up- and down-regulation of proteins in pathways in post-pubertal heifers at the luteal phase compared to pre-pubertal heifers.

\begin{tabular}{cccc}
\hline Pathways & DA Proteins & Up-Regulated & Down-Regulated \\
\hline Glycolysis & 9 & 9 & 0 \\
TCA cycle & 12 & 12 & 0 \\
Pentose phosphate pathway & 7 & 7 & 0 \\
Oxidative phosphorylation & 24 & 24 & 0 \\
Fatty acid metabolism & 9 & 9 & 0 \\
Branched chain amino-acid degradation & 11 & 10 & 1 \\
Terpeniod backbone biosynthesis & 4 & 4 & 0 \\
Cholesterol metabolism & 10 & 8 & 2 \\
Cholesterol efflux & 3 & 0 & 3 \\
Ovarian steroidogenesis & 15 & 11 & 4 \\
Oocyte maturation and oocyte meiosis & 12 & 8 & 4 \\
cAMP signaling & 6 & 2 & 4 \\
Estrogen signaling & 8 & 5 & 3 \\
Cell division & 6 & 4 & 3 \\
Microtubule processing & 4 & 10 & 0 \\
Regulation of actin cytoskeleton & 20 & 5 & 10 \\
Focal adhesion & 28 & 3 & 23 \\
\hline
\end{tabular}


Table 2. Cont.

\begin{tabular}{cccc}
\hline Pathways & DA Proteins & Up-Regulated & Down-Regulated \\
\hline Cell matrix adhesion & 5 & 0 & 5 \\
ECM receptor interaction & 17 & 2 & 15 \\
Protein processing & 21 & 20 & 1 \\
Ribosome & 35 & 35 & 0 \\
Translation & 38 & 37 & 1 \\
Nucleosome assembly & 15 & 1 & 14 \\
Regulation of transcription & 11 & 5 & 6 \\
Glutathione metabolism & 11 & 7 & 4 \\
Cell redox homeostasis & 13 & 13 & 0 \\
\hline
\end{tabular}

TCA: Tricarboxylic Acid Cycle. cAMP: Cyclic Adenosine Monophosphate.

We observed the functional annotation of DA proteins, their associated GO terms, and pathways to manually curate protein interactions. Manual annotation of DA proteins allowed grouping into known interaction pathways that provide an overview of the ovarian proteome in the context of puberty. We identified a group of DA proteins associated with steroidogenesis (progesterone synthesis) at the luteal phase in post-pubertal heifers (Figure 2). The DA proteins related to progesterone synthesis were up-regulated in post-pubertal heifers compared to pre-pubertal heifers, which was exactly as expected since samples were collected at the luteal phase after puberty and a functioning CL was present. In this sense, up-regulated proteins post-puberty would be mostly from increased expression by CL cells. Meanwhile, the down-regulated proteins would correspond to proteins that had their expression reduced when granulosa cells were luteinized.

Another group of DA proteins was related to regulation of oocyte maturation/arrest. Clustering by DAVID included nine proteins in progesterone-mediated oocyte maturation, estrogen, and cyclic adenine monophosphate (cAMP) signaling (Figure 3). The DA proteins from these clusters, when manually curated with evidence from the previous literature, seem involved in the regulation of oocyte maturation/arrest upon puberty in post-pubertal heifers. The DA proteins linked to oocyte maturation would be present in granulosa cells, which regulate and signal to promote oocyte maturation or arrest depending on the phase of the estrus cycle. Granulosa cells of the ovulatory follicle are luteinized and become CL cells post-puberty and at the luteal phase oocyte arrest is observed in the non-ovulatory follicles.

As an overall trend, the up-regulated proteins were involved in metabolic pathways and steroidogenesis while down-regulated proteins seemed to be involved in the regulation of CL function and oocyte maturation/arrest through the extracellular matrix and focal adhesion proteins in post-pubertal heifers at the luteal phase compared to pre-pubertal heifers (Table 3). Also, twenty-two DA proteins were identified as "uncharacterized" according to Uniprot (Table S1). 


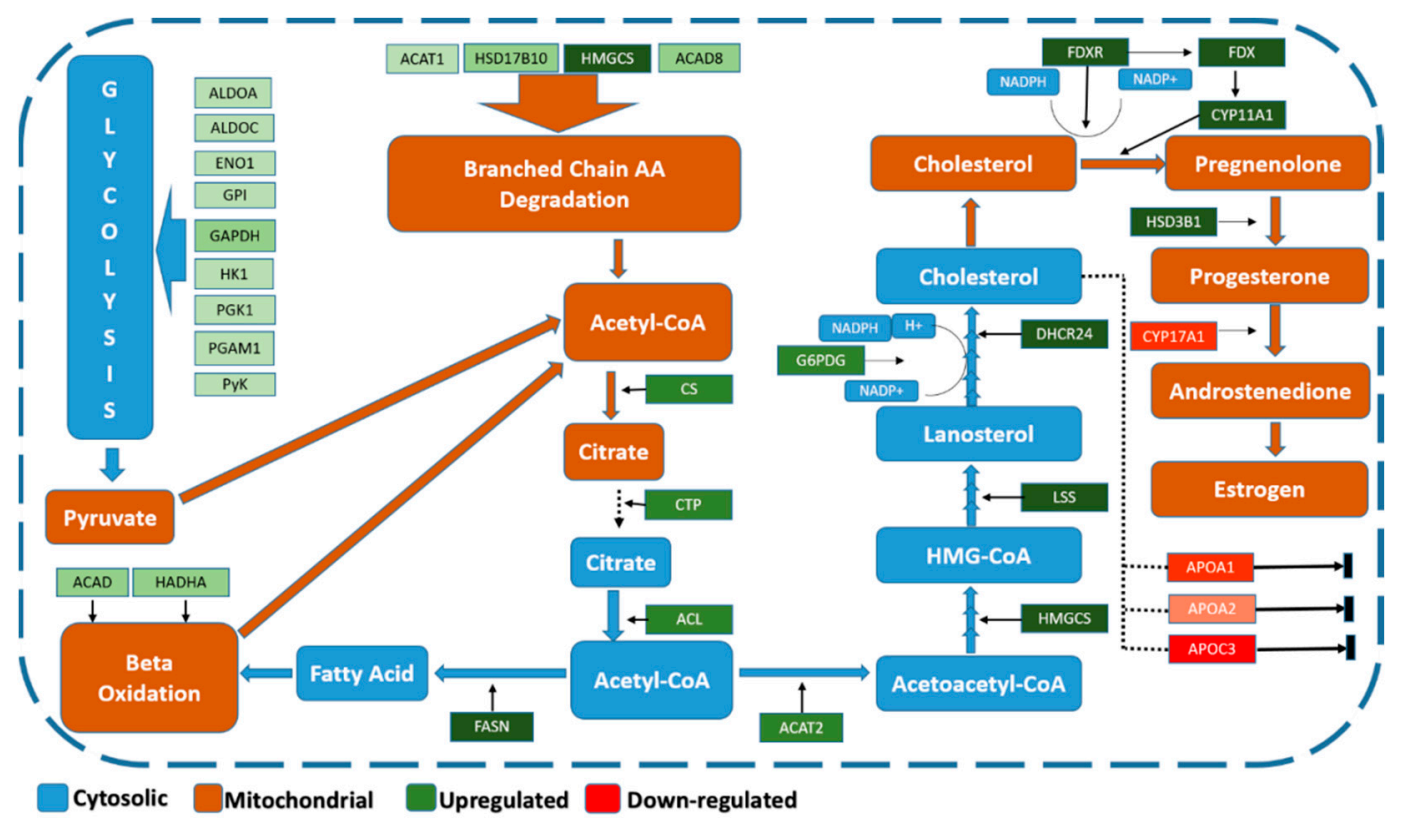

Figure 2. Proteins related to steroidogenesis differentially expressed in ovaries of post-pubertal heifers at the luteal phase compared to pre-pubertal Brahman heifers. Green and red tags indicate up- and down-regulated proteins, respectively, and their color intensity is related to the fold change level of proteins. Blue tags indicate literature-reported cytosolic compounds and processes. Brown tags indicate literature-reported mitochondrial compounds and processes. Fructose biphosphate aldolase-A (ALDOA). Fructose biphosphate aldolase-C (ALDOC). Alpha enolase (ENO1). Glycosylphosphatidyle inositol (GPI). Glyceraldehde-3-phosphate dehydrogenase (GAPDH). Hexokinase-1(HK1). Phosphoglycerate Kinase (PGK1). Phosphoglycerate mutase-1 (PGAM1). Pyruvate kinase (PyK). Acyl CoA dehydrogenase (ACAD). Hydroxyacyl-CoA dehydrogenase/3-ketoacyl-CoA thiolase/enoyl-CoA hydratase, alpha subunit (HADHA). Fattyacid synthase (FASN). ATP citrate lyase (ACL). Carboxylic acid transport protein (CTP). Citrate synthase (CS). Acetyle CoA acetyle transferase (ACAT2). Glucose-6-phosphate dehydrogenase (G6PGD). Acetyle CoA acetyle transferase-1 (ACAT1). 3-Hydroactle-CoA dehdrogenase-2 (HSD17B10). Hydromethylglutaryl-CoA synthase (HMGCS). Isobutaryl-CoA dehydrogenase (ACAD8). Lanosterole synthase (LSS). 24-Dehydrocholeaserole reductase (DHCR24). Ferridoxin reductase (FDXR). Ferridoxin (FDX). Cytochrome P450 family 11 subfamily A member 1 (CYP11A1). 3-beta-hdroxysteroid dehydrogenase (HSD3B1). Cytochrome P450 family 17 subfamily A member 1 (CYP17A1). Apolipoprotein-A1 (APOA1). Apolipoprotein-A2 (APOA2). Apolipoprotein-C3 (APOC3). 


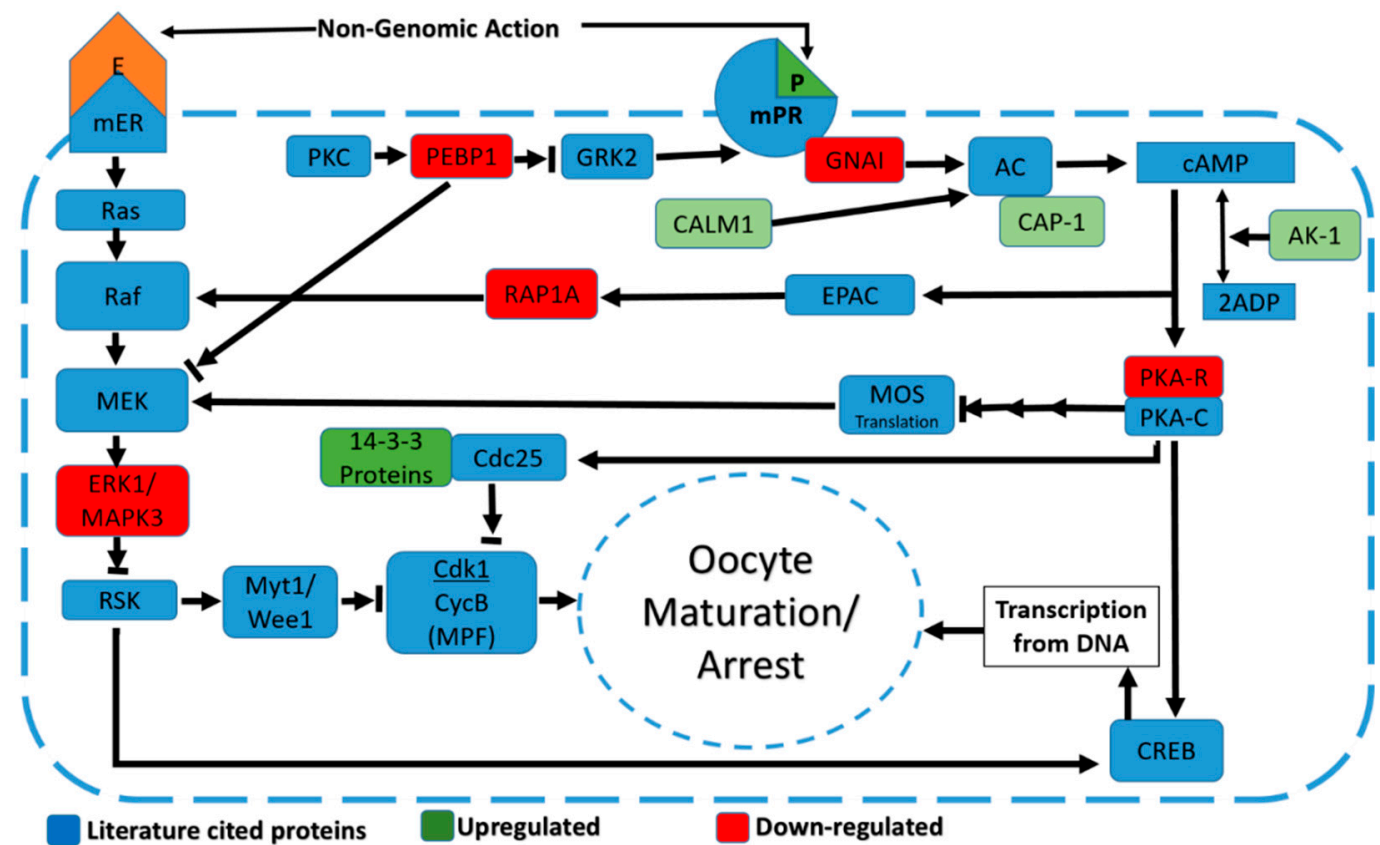

Figure 3. Differentially abundant proteins related to oocyte maturation/arrest through progesterone and MAPK signaling in ovaries of post-pubertal heifers at the luteal phase compared to pre-pubertal heifers. Green and red tags indicate up- and down-regulated proteins, respectively, and their color intensity is directly related to the fold change level of proteins. Blue tags indicate literature-reported proteins. Progesterone (P); Estrogen $(\mathrm{E})$; Membrane progesterone receptor (mPR); Adenyl cyclase (AC); Cyclic adenosine monophosphate (cAMP); G-inhibitory protein (GNAI); Calmodulin-1 (CALM1); Adenlyl cyclase associated protein (CAP-1); Adenylate Kinase-1 (AK-1); Protein kinase-A regulatory subunit (PKAR); Protein kinase-A catalytic subunit (PKAC); Exchange factor directly activated by cAMP (EPAC); Ras related protein-1A (RAP1A); Mos protein (Mos); Cel division cycle protein 25 (Cdc25); Protein Kinase-C (PKC); Phosphatidylethanolanim binding protein (PEBP1); Beta adrenergic receptor kinase2 (GRK2); Membrane Estrogn receptor (mER); Mitogen activated protein kinase (MEK); Mitogen activated protein kinase-3 (MAPK3); Ribosomal S6 Kinase (RSK).; Myelin transcription factor-1 (Myt1); Wee1 like protein kinase (Wee1); Cell division kinase-1 (Cdk1).; Cyclin-B (CycB); cAMP responsive element binding protein (CREB). 
Table 3. Top twenty up- and down-regulated proteins from the current study and their function according to the cited literature, in the context of puberty and fertility.

\begin{tabular}{|c|c|c|c|c|}
\hline Proteins & $\log _{2}$ Fold Change & Cellular Process & Puberty-Related Function & Reference \\
\hline DHCR24 & 3.28 & Cholesterol synthesis & Steroidogenesis & Robert K. Murray et al. [41] \\
\hline FDX1 ADX & 3.02 & Electron transfer & Steroidogenesis & Miller et al. [42] \\
\hline HSD3B & 2.92 & Progesterone synthesis & Steroidogenesis & Miller et al. [43] \\
\hline HMGCS & 2.91 & Cholesterol synthesis & Steroidogenesis & Russell et al. [44] \\
\hline LSS & 2.87 & Lanosterol synthesis & Steroidogenesis & Christianson et al. [45] \\
\hline FDXR & 2.66 & Electron transfer & Steroidogenesis & Miller et al. [42] \\
\hline TPD52 & 2.66 & Cell cycle regulation & Scrotal circumference association & Meirelles et al. [46] \\
\hline QPRT & 2.13 & NAD+ biosynthesis & Antioxidation in steroidogenesis & Aguilera-Méndez, Fernández-Lainez et al. [47] \\
\hline FASN & 2.11 & Fatty acid synthesis & Up-regulation of steroidogenesis & Wakil et al. [48] \\
\hline CYP11A1 & 2.11 & Pregnenolone synthesis & Up-regulation of steroidogenesis & Miller et al. [43] \\
\hline ACLY & 1.75 & Citrate synthesis & Up-regulation of steroidogenesis & Guay, Madiraju et al. [49] \\
\hline IDH3A & 1.65 & TCA cycle & Up-regulated in old age oocytes & Itami, Kawahara-Miki et al. [50] \\
\hline Uncharacterized & 1.48 & & & \\
\hline NNT & 1.37 & Electron transport chain & Antioxidant in steroidogenesis & Roucher-Boulez, Mallet-Motak et al. [51] \\
\hline NDUFC2 & 1.30 & Electron transport chain & Antioxidant in oocyte maturation & Payton, Rispoli et al. [52] \\
\hline ACAT2 & 1.29 & Acetyl-CoA metabolism & Up-regulation of steroidogenesis & Russell et al. [44] \\
\hline LONP1 & 1.26 & Mitochondrial activity & Up-regulation of steroidogenesis & Rone, Midzak et al. [53] \\
\hline AIFM1 & 1.26 & Pro-apoptotic activity & Atresia of antral follicles & Craig, Singh et al. [54] \\
\hline PTN & 1.21 & Focal adhesion & Female infertility & Muramatsu, Zou et al. [55] \\
\hline RBP1 & 1.20 & Retinoic acid signaling & Oocyte maturation & Salhab, Tosca et al. [56] \\
\hline ASPN & -1.99 & Extracellular matrix & $\begin{array}{l}\text { Associated with secondary follicle growth } \\
\text { Transcription for CL functioning }\end{array}$ & $\begin{array}{l}\text { Aoyama, Shiraishi et al. [57] } \\
\text { Meldi, Gaconnet et al. [58] }\end{array}$ \\
\hline $\mathrm{H} 3 \mathrm{~F} 3 \mathrm{~A} / \mathrm{B}$ & -1.46 & Nucleosome assembly & $\begin{array}{c}\text { Chromatin remodeling in } \\
\text { oocyte maturation }\end{array}$ & Fournier, Dufort et al. [59] \\
\hline EIF4B & -1.24 & Translation & Translation in oocyte maturation & Ellederová, Cais et al. [60] \\
\hline SERPINA3 & -1.23 & Extra cellular matrix & $\begin{array}{l}\text { Decreased abundance in 11-days CL } \\
\text { Oocyte competence associated }\end{array}$ & $\begin{array}{l}\text { Zalman, Ireland et al. [61] } \\
\text { Hamel, Dufort et al. [62] }\end{array}$ \\
\hline Uncharacterized PTI & -1.15 & & & \\
\hline $\mathrm{TN}-\mathrm{X}$ & -1.12 & Extracellular matrix & $\begin{array}{l}\text { Marker for CL function. } \\
\text { Up-regulated in antral follicles } \\
\text { and competent oocytes }\end{array}$ & $\begin{array}{l}\text { Dominguez, Cho [63] } \\
\text { Cibelli, Iager et al. [64] }\end{array}$ \\
\hline
\end{tabular}


Table 3. Cont

\begin{tabular}{|c|c|c|c|c|}
\hline Proteins & $\log _{2}$ Fold Change & Cellular Process & Puberty-Related Function & Reference \\
\hline ApoC3 & -1.09 & Cholesterol efflux & $\begin{array}{l}\text { Steroidogenesis, down-regulated in cumulus cells of } \\
\text { mature oocytes }\end{array}$ & Shao, Chian et al. [65] \\
\hline SERPINE2 & -1.01 & Extracellular matrix & $\begin{array}{l}\text { Differential expression in } \\
\text { antral follicle and mature oocytes }\end{array}$ & Bédard, Brûlé et al. [66] \\
\hline SERPINA3.3 & -1.00 & Extracellular matrix & Expressed in follicular fluid during oocyte maturation & Ducolomb, González-Márquez et al. [67] \\
\hline Uncharacterized GSTM & -0.99 & & & \\
\hline H2AFY2 & -0.98 & Nucleosome assembly & Repressed transcription on meiosis & Wang, Xu et al. [68] \\
\hline LMCD1 & -0.96 & $\begin{array}{l}\text { Regulation of } \\
\text { transcription }\end{array}$ & Regulation of transcription in spermatogenesis & Griffin, Dunmore et al. [69] \\
\hline BLT & -0.93 & Proteolytic activity & Second maturation of oocyte & Yamane et al. [70] \\
\hline VCAN & -0.90 & Extracellular matrix & Oocyte maturation quality & Dunning, Watson et al. [71] \\
\hline PRELP & -0.82 & Extracellular matrix & Follicular development & Irving-Rodgers and Rodgers et al. [72] \\
\hline LAMB2 & -0.82 & Extracellular matrix & Decreases after oocyte maturation & Budna, Celichowski et al. [73] \\
\hline H1F0 & -0.82 & Nucleosome assembly & Oocyte maturation & $\mathrm{Niu}, \mathrm{Zi}$ et al. [74] \\
\hline FST & -0.82 & TGF- $\beta$ signaling & $\begin{array}{c}\text { Progesterone synthesis by suppressing TGF- } \beta \\
\text { signaling } \\
\text { Oocyte maturation }\end{array}$ & $\begin{array}{l}\text { Kayani, Glister et al. [75] } \\
\text { Adona, Leal et al. [76] }\end{array}$ \\
\hline DDX17 & -0.80 & Transcription & Differential expression in cumulus cells & Assou, Haouzi et al. [77] \\
\hline FBN1 & -0.78 & Extracellular matrix & Oocyte quality marker & Powell, Manandhar at al. [78] \\
\hline
\end{tabular}


The processes involved in regulation of ribosome and translation were up-regulated, except for some specific down-regulated proteins like eukaryotic translation initiation factor-4B (EIF4B). The DA proteins involved in repression of transcription, such as various histones, LIM, and cysteine-rich domains protein-1 (LMCD1), hepatoma-derived growth factor (HDGF), and heterochromatin protein 1 binding protein-3 (HP1BP3), were down-regulated. Nine SERPINs, extracellular matrix proteins, were identified as DA, out of which eight were down-regulated in post-pubertal heifers compared to pre-pubertal heifers. Three of these proteins, SERPINE2, SERPINA3, and SERPINA3-3, were among the top twenty down-regulated proteins in our dataset (Table 3). This down-regulation of extracellular matrix (ECM) proteins may also be linked to the formation and function of the CL cells (see the discussion).

Analysis by STRING revealed interactions between proteins related to pleiotrophin signaling, cytoskeleton arrangement, focal adhesion, and spindle fiber arrangement (Figure 4). It is important to mention that pleiotrophin was a highly up-regulated protein in post-pubertal heifers at the luteal phase compared to pre-pubertal heifers. Pleiotrophin seems to play an important role while interacting with focal adhesion, cytoskeleton, and spindle assembly proteins during the onset of puberty and the establishment of progesterone signaling.

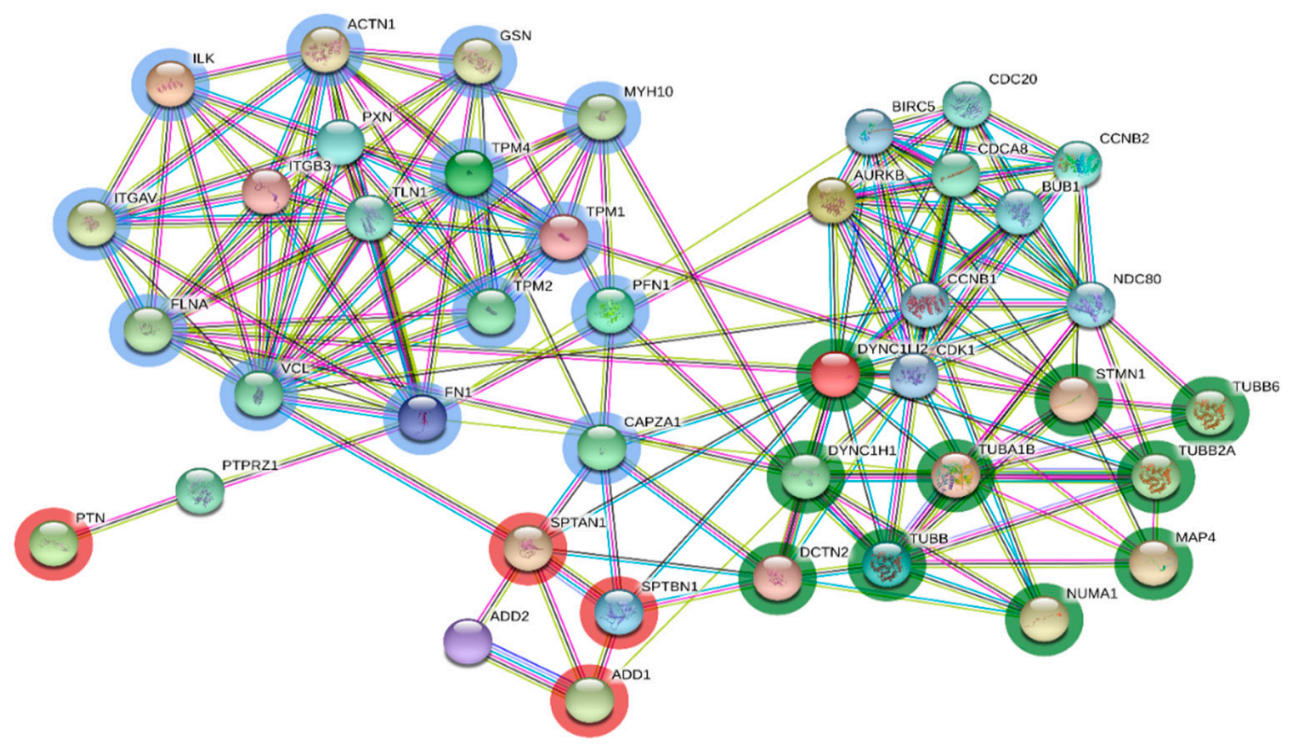

Figure 4. Protein-protein interaction for the subset of differentially abundant proteins involved in pleiotrophin signaling, focal adhesion, and cytoskeleton and microtubule processing under the influence of progesterone signaling. Blue circled nodes indicate proteins which are part of cytoskeleton and focal adhesion. Green circled nodes indicate proteins included in microtubule processing. Red circled nodes indicate proteins interacting with both blue and green nodes. Nomenclature of proteins is given in Table 1.

Using Uniprot ID information we were able to annotate the coding genes for all the DA proteins. We investigated the location of these genes to discover if they could be linked to any reproductive QTL. Ten DA proteins were coded by genes associated with reproductive traits according to QTL position (Table 4). 
Table 4. Ten genes that code for differentially abundant proteins in the current experiment mapped to genomic regions associated with reproductive traits in cattle.

\begin{tabular}{|c|c|c|c|c|}
\hline No. & Gene & $\begin{array}{l}\text { Chromosome/Locus } \\
(\mathrm{Mbp})\end{array}$ & Traits Associated & Reference \\
\hline 1 & NNT & $20(31.2)$ & Length of reproductive life & $\begin{array}{l}\text { Kolbehdari, Wang et al. } \\
\text { [79] }\end{array}$ \\
\hline 2 & ACAT2 & $9(97.5)$ & $\begin{array}{l}\text { Length of reproductive life } \\
\text { Conception rate } \\
\text { Daughter pregnancy rate }\end{array}$ & Dikmen, Wang et al. [80] \\
\hline 3 & TXN & $5(75.3)$ & Daughter pregnancy rate & Ortega, Denicol et al. [81] \\
\hline 4 & $E Z R$ & $9(96.6)$ & $\begin{array}{c}\text { Length of reproductive life } \\
\text { Calving ease }\end{array}$ & $\begin{array}{c}\text { Kolbehdari, Wang et al. } \\
\text { [79] }\end{array}$ \\
\hline 5 & TCP1 & $1(6.5)$ & Conception rate & Cochran, Cole et al. [82] \\
\hline 6 & ССТ8 & $1(6.5)$ & Conception rate & Cochran, Cole et al. [82] \\
\hline 7 & CAPN1 & $\begin{array}{l}29(32.5-34.5) \\
29(32.5-34.5)\end{array}$ & $\begin{array}{l}\text { Post-partum anestrus } \\
\text { interval (PPAI) } \\
\text { IGF-1 levels }\end{array}$ & $\begin{array}{l}\text { Collis, Fortes et al. [83] } \\
\text { Collis, Fortes et al. [83] }\end{array}$ \\
\hline 8 & $L A P 3$ & $6(38.6)$ & Calving ease & $\begin{array}{c}\text { Bongiorni, Mancini et al. } \\
\text { [84] }\end{array}$ \\
\hline 9 & FST & $20(25.6)$ & Conception rate & Ortega, Denicol et al. [81] \\
\hline 10 & SERPINE2 & $2(112.9)$ & Fertilization rate & Cochran, Cole et al. [85] \\
\hline
\end{tabular}

We also compared our dataset of DA proteins with the list of differentially expressed (DE) genes for the same ovarian samples from post- versus pre-pubertal heifers which was previously reported by our group [29]. Comparative analysis resulted in 126 features in common, i.e., DA proteins that were also DE genes in the previous RNA-sequencing analyses. We performed correlation and regression analysis for these 126 proteins and genes. The correlation coefficient $(r)$ between expression of genes and abundance of respective proteins was positive: $r=0.54$. In regression analysis, we regressed the fold change in differential expression of genes (independent variable) against the fold change in differential abundance of their respective proteins (dependent variable). Regression coefficient was a positive value of 0.61 while the coefficient of determination $\left(R^{2}\right)$ was calculated as 0.28 with $p$ value $<0.0001$ (Figure 5). In short, the abundance level of DA proteins was correlated to the expression of DE genes.

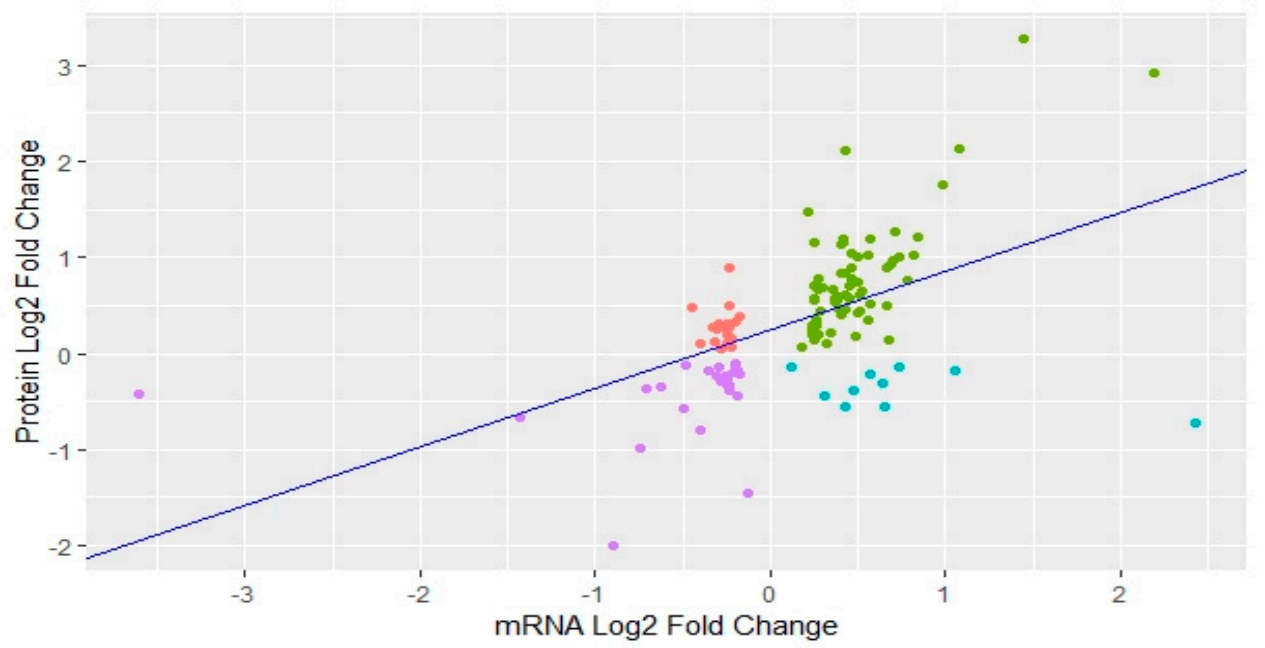

Figure 5. Scatter plot showing correlation between protein abundance and respective gene expression. Green: up-regulated proteins and up-regulated mRNA. Red: up-regulated proteins and down-regulated mRNA. Purple: down-regulated proteins and down-regulated mRNA. Blue: down-regulated proteins and up-regulated mRNA. 


\section{Discussion}

This study aimed to investigate the genes and pathways involved in ovarian progesterone production - a hallmark of CL function-at the onset of puberty. To this aim, homogenized ovarian samples that represent the entirety of both ovaries were used for proteomics. Ovarian granulosa and theca cells are crucial for steroid synthesis and oocyte maturation, and so their activity is relevant to maintenance of subsequent pregnancy through progesterone signaling. After puberty (first ovulation), a CL is formed and it produces progesterone, which is necessary to maintain early pregnancy, and hence contributes to fertility [86,87]. The presence of the CL alters ovarian gene expression [88]. The identified DA proteins in post-pubertal heifers at the luteal phase compared to pre-pubertal heifers indicate their importance to CL function, as the presence of the CL cells represents the main difference between the two physiological stages. This DA proteins might have a role in puberty and subsequent fertility as they were linked in this work to essential ovarian activities. In the following sections, DA proteins are grouped and discussed according to their ovarian function.

\subsection{Metabolic Pathways}

Up-regulated DA proteins were found to be related to metabolic pathways such as glycolysis, oxidative phosphorylation, and beta-oxidation. Up-regulation of glycolysis and genes which involve glycolysis and steroidogenesis have been reported in the oocytes of post-pubertal cows when compared to pre-pubertal cows $[29,89]$. Oxidative phosphorylation was an enriched pathway in the list of up-regulated proteins in our results. Up-regulation of oxidative phosphorylation affects steroidogenesis through steroidogenesis acute regulatory protein (StAR) [90]. Stimulation of beta-oxidation of fatty acids for oocyte maturation through protein kinase-A signaling has also been reported in mice [91]. Up-regulation of proteins is linked to metabolic pathways in post-pubertal heifers at the luteal phase compared to pre-pubertal heifers and evidence from the cited literature suggests that these pathways play a role in progesterone synthesis. Progesterone signaling contributes to pubertal development according to the Gonodostattheory and the observation that a first short cycle is often necessary to the establishment of normal cycling in bovine species [14]. Therefore, and in the context of this study, DA proteins related to metabolic pathways might contribute to both CL function and pubertal development.

\subsection{Transcription and Translation}

We identified DA proteins that regulate transcription. Regulatory patterns of gene transcription and translation during oocyte growth, oocyte maturation, and luteinization of granulosa cells are timing specific [92,93]. Histones play a crucial role in transcriptional regulation [68]. Histone H3.3 was found to be one of the most down-regulated proteins post-puberty (fold change $=-1.46$ ). Specific methylation of $\mathrm{H} 3$ is associated with repression of $\alpha$-inhibin, which is important for CL function and progesterone synthesis [58]. H3.3 and H4 interfere with meiosis and their depletion results in primary oocyte death and zygotic and early embryonic deaths [68]. Macro-H2A, HDGF, HP1BP3, and LMCD1 were down-regulated in post-pubertal heifers at the luteal phase in our data. These proteins are involved in the repression of transcription [94-97]. Down-regulation of specific histones and transcription repression proteins indicate enhanced transcription in post-pubertal heifers at the luteal stage compared to pre-pubertal heifers. These regulatory DA proteins probably have a role in progesterone synthesis by CL cells. These same proteins might be involved in meiotic oocyte maturation/arrest in pre-ovulatory follicles in coordination with progesterone signaling.

Increased translation and ribosomal activity, which is related to steroidogenic synthesis after LH stimulation, was observed in our data and has been seen in a previous work [98]. Some ribosomal proteins were DA in this study namely, RPL30, RPL27a, RPS8, RPS12, and RPLPO, and have also been found to be differentially expressed in mature buffalo oocytes compared to pre-pubertal oocytes [99]. Future work could use ovarian dissection to isolate granulosa cells and oocytes to investigate which 
cell type contributes to the significant difference observed for DA proteins. Overall, DA proteins associated with regulation of transcription and translation were found to be up-regulated, which could be explained by very active CL cells compared to the relatively less active cells in pre-pubertal ovaries.

All translation- and ribosome-related DA proteins were up-regulated in our data except for the eukaryotic initiation factor EIF4B. Translation of maternal mRNAs is regulated by secondary structures in UTRs $[93,100]$. EIF4B was down-regulated $(F C=-1.24)$ in post-pubertal heifers. EIF4B stimulates EIF4A to unwind secondary structures from maternal mRNAs to enable attachment of ribosomes for translation initiation during oocyte maturation [60,101]. Time-specific translation of maternal mRNAs is necessary for oocyte maturation [60]. At luteal phase post-puberty, where no oocyte maturation is expected, the selective down-regulation of EIF4B indicates that this protein might regulates translation that is specific to oocyte maturation. Once more, isolation of oocyte gene expression would be important to confirm this idea.

\subsection{Complement System}

The list of down-regulated proteins post-puberty was enriched for the 'Complement and coagulation cascade pathway'. Maintenance of mature CL is dependent on lowering the immune system in CL cells [102]. Down-regulation of complement factors, which are part of the immune system, at the luteal phase in post-pubertal heifers is indicative of a mature CL being present and functional. Progesterone measurements also confirmed that post-pubertal heifers had functioning CLs in our dataset. Complement component $\mathrm{C} 3$ has also been identified as positively associated with oocyte maturation in pigs [103]. Another study has identified complement components C3, C4, C7, C8, C9, C-H, and C-I in human follicular fluid and associated these with oocyte maturation [104]. Differential abundance of complement components in post-pubertal heifers at the luteal phase compared to pre-pubertal heifers in our study supports the role of these proteins in CL maintenance and pubertal development. Both phenomena would have implications for subsequent fertility.

\subsection{Extracellular Matrix Proteins}

Extracellular matrix and focal adhesion proteins are important in mediating paracrine signaling in ovaries for follicular development and CL functions [105,106]. Fibronectin and asporin are examples of ECM proteins that were DA. Fibronectin was increased in abundance post-puberty, at the luteal phase. Increased fibronectin is indicative of a functioning CL [107]. Asporin (ASPN) was the most down-regulated protein in post-pubertal heifers at the luteal phase compared to pre-pubertal heifers. ASPN in theca cells is associated with growth of secondary follicles in the gonadotrophins independent stage [57]. The up-regulation of fibronectin and the down-regulation of asporin both tell a story of a functioning CL and reduced follicular growth, which could be expected by the presence of CL cells at the luteal phase which were not present before.

Some ECM proteins, such as SERPINs and Tenascin-X (TNXB), might be involved in oocyte maturation. Nine SERPIN proteins, including SERPINE2, were down-regulated in post-pubertal heifers compared to pre-pubertal heifers. ECM proteins, including SERPINs and ITIH1, are found to be specific to oocyte maturation and SERPINE2 has been proposed as a biomarker for oocyte maturation [108,109]. Tenascin-X (TNXB) was among the top down-regulated proteins $(F C=-1.12)$ in post-pubertal heifers in our results. Transcription of the TNXB gene is increased in pre-ovulatory follicles and pregnancy competent oocytes $[64,110]$. As we did not separate specific cell types in our study, the role of these nine SERPINs and TNXB in oocyte maturation requires validation.

Agrin (AGRN), lamin-A (LMNA), lamin-B (LMNB), laminin, clusterin (CLU1) and vimentin (VIM) are also ECM proteins that were down-regulated in our data. Remodeling of extracellular matrix proteins and adhesion proteins has also been reported in the leutinization of cells that form the CL. Proteins such as integrin-v $\alpha$ and laminin are associated with leutinization [111]. Lamins and laminins are part of the basal lamina that separates granulosa cells from theca cells in pre-ovulatory follicles. They are important ECM proteins that mediate the interactions between granulosa cells, the thecal 
layer, and the oocyte. This basal lamina degrades during CL formation [107]. Decreased abundance of lamins in our study agrees with the presence of functioning CL cells post-puberty, a major contrast to the pre-pubertal samples. Lamins are increased in expression during meiotic oocyte maturation [112]. Laminin A and B have increased expression levels associated with oocyte maturation in mice [113]. The reverse, down-regulation, is expected in the luteal phase. Similarly, CLU1 was down-regulated in our data, which could be expected for the luteal phase since increased levels of CLU1 have been related to oocyte maturation in bovine previously [56]. Differential abundance of ECM proteins in post-pubertal as compared to pre-pubertal heifers probably relates to CL formation and function, with implications for pubertal development and subsequent fertility.

\subsection{Steroidogenesis}

The up-regulation of steroidogenic proteins in our study can probably be explained by the presence of functioning CL cells post-puberty which were absent pre-puberty. Steroidogenesis starts with the precursor acetyl-CoA, which leads to synthesis of cholesterol and finally steroid hormones. We observed 32 DA proteins between pre- and post-pubertal Brahman heifers that are relevant to steroidogenesis. Highlighting these DA proteins, we were able to annotate the steroidogenesis pathway in Bos indicus animals.

Acetyl-CoA results from different metabolic pathways, including glycolysis. Nine up-regulated proteins from our results play a role in glycolysis and result in pyruvate synthesis [114], which produces acetyl-CoA in a subsequent reaction [115]. Acetyl-CoA is converted to citrate by citrate synthase (CS). Citrate can enter the tricarboxylic acid cycle or be transported to cytosol by citrate transport protein (CTP). Citrate is cleaved and converted into acetyl-CoA and oxaloacetate by ATP citrate lyase (ACL) [49]. Acetyl-CoA can be used to synthesize fatty acids or cholesterol or to enter into thetricaboxylic acid cycle $[115,116]$. The above-mentioned proteins CS, CTP, and ACL were up-regulated in our data. Up-regulation of proteins in glycolysis and subsequent steps indicates their important role in contributing acetyl-CoA as a precursor for up-regulation of steroidogenesis at puberty.

Bothde novo synthesis and beta-oxidation of fatty acids were observed. Fatty acid synthase (FASN) was up-regulated post-puberty. FASN converts acetyl-CoA to palmitate, the most abundant saturated fatty acid [48]. Enzymes acyl-CoA dehydrogenase (ACAD) and a tri-functional protein (HADHA) were up-regulated post-puberty. These enzymes, through beta-oxidation, contribute acetyl-CoA to steroidogenesis [41,117]. The enzymes involved in branched chain amino degradation, including acetyl-CoA acetyltransferase-1 (ACAT1), 3-hydroxymethylglutaryl-CoA synthase-1 (HMGCS1), hydroxysteroid-17-beta dehydrogenase-10 (HSD17B10), and acyl-CoA dehydrogenase (ACAD8) were up-regulated post-puberty. Branched chain amino-acid degradation also produces acetyl-CoA [118]. Increased abundance of DA proteins belonging to fatty acid synthesis, beta-oxidation, and branched chain amino-acid degradation suggests increased availability of acetyl-CoA for steroidogenesis in the luteal phase post-puberty.

Different enzymes converting acetyl-CoA to cholesterol, including acetyl-CoA acetyl transferase2 (ACAT2), HMG-CoA synthase, lanosterol synthase (LSS), 24-dehydrocholesterol reductase (DHCR24), and glucose 6 phosphate dehydrogenase (G6PDH) were also up-regulated post-puberty. ACAT2 converts acetyl-CoA to acetoacetyl-CoA, which is further converted to hydromethylglutaryl-CoAby HMG-CoA synthase [44]. HMG-CoA in further reactions is converted to oxidosqualene, which is converted to lanosterol by LSS [45]. DHCR24 converts desmosterol to cholesterol and all reducing reactions during cholesterol synthesis are catalyzed by G6PDH [41,119]. Therefore, these up-regulated proteins contribute to synthesis of cholesterol in the pathway upstream to steroid hormone production.

The apolipoproteins A-I, A-II, and C-III were down-regulated post-puberty. Apolipoproteins sustain cholesterol homeostasis in cells, removing it when it becomes excessive to avoid cellular cholesterol toxicity [120-122]. Up-regulation of enzymes that contribute to cholesterol 
synthesis and down-regulation of cholesterol efflux proteins together indicates increased supply of cholesterol for steroidogenesis post-puberty.

Cholesterol side-chain cleavage enzyme (CYP11A1), ferredoxin (FDX), ferredoxin reductase (FDXR), and 3-beta-hydroxysteroid dehydrogenase (HSD3B1) were up-regulated while steroid 17-alpha-hydroxylase (CYP17A1) was down-regulated in our results. Conversion of cholesterol to pregnenolon is mediated by CYP11A1. FDXR and FDX help in electron transfer for this reaction. Pregnenolon is converted to progesterone by 3-beta-hydroxysteroid dehydrogenase (HSD3B1) [42,43]. CYP17A1 converts progesterone to androstenedione [123], which in further reactions is converted into estrogen [124]. Up-regulation of progesterone synthesis proteins and down-regulation of estrogen-related proteins indicate high levels of progesterone production, which is typical of the luteal phase.

The process of steroidogenesis is the same for both progesterone and estrogen up to the synthesis of cholesterol. The up-regulation of this process up to cholesterol synthesis may be important for both the estrogenic and the luteal phase post-puberty. To confirm the overall relevance of these DA proteins to the onset of puberty, future research could compare pre-pubertal heifers to post-pubertal heifers in all phases of the estrus cycle.

\subsection{Progesterone Signaling Regulating Puberty and Fertility}

Progesterone and its membrane receptors are involved in oocyte maturation in the pre-ovulatory follicle, in fertilization processes, and in the maintenance and development of the pregnancy [125-127]. These phenomena, which are affected by progesterone signaling, contribute to overall female fertility. Progesterone signaling is complex and some of the same pathways are relevant to mature CL cells and to oocyte maturation. The DA proteins G inhibitory protein GNAI2, adenylyl cyclase associated protein (CAP-1), adenylate kinase (ADK), and protein kinase A regulatory subunit II $\alpha$ and $\beta$ (PRKAR2 $\alpha$ and PRKAR2 $\beta$ ) all contribute to activate the transcription factor cAMP responsive regulatory element binding protein (CREB). In turn, CREB regulates the transcription of proteins related to CL functioning $[128,129]$. The fact that these proteins are DA herein might be explained by the presence of the CL being unique to post-pubertal heifers.

Some of these DA proteins are also known for their roles in progesterone signaling related to oocyte maturation: GNAI2, CAP-1, and ADK are, for example. GNAI2 was down-regulated whileCAP-1 and ADK were up-regulated in post-pubertal heifers compared to pre-pubertal heifers. These proteins are involved in progesterone-mediated oocyte maturation/arrest. Progesterone through membrane progesterone receptors activates GNAI2, which inhibits adenylyl cyclase (AC) to suppress levels of cAMP in oocytes [24,130-134]. Similarly, CAP-1 and ADK are also involved in the regulation of cAMP levels $[135,136]$. Suppression of cAMP relieves oocytes from meiotic arrest and hence causes oocyte maturation $[130,132,133,137,138]$. PRKAR2 $\alpha$ and PRKAR2 $\beta$ were also down-regulated in post-pubertal heifers compared to pre-pubertal heifers. Interestingly, increased levels of PRKAR2 $\alpha$ and PRKAR2 $\beta$ are associated with progesterone-, mediated oocyte maturation [24,131].

Tyrosine monoxygenase activation proteins YWHAG, YWHAE and YWHAZ were up-regulated in post-pubertal heifers compared to pre-pubertal heifers. These proteins suggestively bind to Cdc25 and prevent its binding to meiosis promoting factor (MPF) [24,139-141]. As a result, oocyte maturation is prevented when YWHAG, YWHAE, and YWHAZ are up-regulated.

Granulosa cells contribute to oocyte maturation at the pre-ovulatory stage and then contribute to the maintenance of pregnancy after being transformed into luteal cells. Both of these phenomena are associated with progesterone signaling at two different stages of the estrous cycle. Low levels of progesterone (and other factors) produced by granulosa cells facilitate follicular growth and oocyte maturation. High levels of progesterone produced by the CL might contribute to oocyte arrest during the luteal phase. The differential abundance of these progesterone-signaling proteins between ovarian tissues of pre-pubertal heifers and post-pubertal heifers at the luteal phase indicates that these proteins 
are probably differentially regulated in luteinized granulosa cells in the CL compared to non-luteinized granulosa cells.

\subsection{Retinoic Acid Signaling}

Our results revealed increased abundance of retinal dehydrogenase (RALHD-1), protein phosphatase-2A (PPP2R1A), and cellular retinoic acid binding protein (CRABP1). These proteins are relevant to retinoic acid (RA) signaling. Retinoic acid is involved in stimulation of progesterone synthesis in the CL [142]. Also, the direct genomic action of RA signaling or its regulation of other effector pathways aids oocyte maturation $[143,144]$. CRABP1 protein is differentially expressed in different stages of bovine oocyte maturation [56]. It inhibits RA activity and also stimulates PPP2R1A via ERK1/2 kinases to delay the cell cycle $[144,145]$. Cell cycle regulation is probably also important to the formation of the CL via cellular differentiation and proliferation processes, as discussed above.

\subsection{TGF- $\beta$ Signaling in Regulation of Oocyte Maturation/Arrest}

Follistatin (FST), ASPN, biglycan (BGN), decorin (DCN), TGF- $\beta$-induced protein (beta-ig-h3/TGFBIp) and TGF- $\beta 1$-induced transcript-1 protein (TGFBI1/Hic-5) were decreased in abundance in post-pubertal heifers compared to pre-pubertal heifers. FST, ASPN, and DCN inhibit TGF- $\beta$ superfamily members [146-149]. TGF- $\beta$ superfamily members have roles in CL progesterone secretion, follicular growth, and oocyte maturation $[22,150,151]$. TGF- $\beta 1$ is also involved in regression of the CL and its increased levels are associated with decrease in progesterone production [152]. TGF- $\beta 1$ inhibits LH receptors and allows completion of oocyte cytoplasmic maturation $[153,154]$. Support from cited literature and differential abundance of TGF- $\beta$-related proteins suggest that TGF- $\beta$ signaling is important for CL function post-puberty.

\subsection{Pleiotrophin and Progesterone Sinaling on Focal Adhesion, Cytoskeleton, and Microtubules}

We suggest a putative role of pleiotrophin in coordination with focal adhesion and cytoskeleton proteins at the luteal phase in post-pubertal heifers. Cytoskeleton and microtubules play a role in progesterone synthesis and oocyte maturation [155-159]. Pleiotrophin, ITGAv (an integrin), and ADD-1 were up-regulated, while filamin (FLNA) and actinin (ACTN1) were down-regulated in post-pubertal heifers at the luteal phase. Pleiotrophin signaling through ITGAv $\beta 3$ (heterodimer of ITGAv and ITGA $\beta$ ) has been reported [160]. ITGAv $\beta 3$ is involved in phosphorylation of cytoskeleton proteins and focal adhesion proteins, including FLNA and ACTN1 [161,162]. Signaling through integrins down-regulates cytoskeleton structures in cells [162]. Adducin heterodimers, composed of $\beta$-adducin (ADD-2) and $\alpha$-adducin (ADD-1), regulate the actin-spectrin complex in the cytoskeleton [163]. Phosphorylation of ADD-2 by pleiotrophin signaling results in cytoskeletal dissociation [164]. Tubulin- $\alpha$, tubulin- $\beta$ subunits, microtubules-associated protein (MAP), dynein light and heavy chains (DYN), and dynactin (DCTN-2) were up-regulated in post-pubertal heifers compared to pre-pubertal heifers in our results. These proteins are involved in microtubule and spindle fiber assembly and function [165]. Dissociation of the cytoskeleton and microtubules is associated with more progesterone synthesis in granulosa cells [159]. Nuclear mitotic apparatus-1 (NuMA-1) was down-regulated in post-pubertal heifers. NuMA organizes microtubules at spindle poles in coordination with DYN and DCTN [166] and plays an important role in meiotic oocyte maturation by organizing tubulins [167]. Similarly, specific hyper-phosphorylation of ADD-1 causes abnormal assembly of spindle fibers in meiosis and mitosis $[168,169]$. Mitosis-associated proteins are very important in the context of forming the CL since the ceasing of cell division is required for cell differentiation and growth processes that transform granulosa cells into luteal cells [16]. Progesterone, through its membrane receptors, is involved in spindle fiber assembly arrangement at different stages of meiosis during oocyte maturation [126] and during mitosis of granulosa cells [170,171]. Differential abundance of proteins related to the cytoskeleton, spindle fibers, and cell division, corroborated by the cited literature, are evidence for the involvement of these proteins in the formation of the CL. 


\subsection{Association of DA Proteins with Reproductive Traits}

Genes of 10 DA proteins from our study were associated with important reproductive traits according to the animal QTL database [40]. The DA protein ezrin (EZR) was associated with "length of reproductive life" and "calving ease" in cattle [79]. Functionally, ezrin is involved in cytoskeleton arrangement [172]. T-complex protein component-1 (TCP-1) and T-complex protein component-8 (CCT-8) were DA in our data and were associated with "conception rate" in cattle [82]. Both of these chaperone proteins help in folding actin and tubulin in cytoskeleton and spindle formation [173,174]. Calpain-1 (CAPN1) was another DA protein in our data that has been previously associated with two reproductive traits, namely "post-partum anestrous interval" and "IGF-1 levels" [83,175]. CAPN1 seems to play a role in cumulus cell-oocyte complex expansion and oocyte maturation [176] and from our data it seems it might also be involved in CL function. Leucine aminopeptidase (LAP3) is a DA protein associated with "calving ease" in cattle [84]. LAP3 expression increases in theca cells of mature pre-ovulatory oocytes in humans in the presence of high levels of progesterone. It has also been reported to play a role in oocyte maturation in Haemaphysalislongicornis tick [177,178]. FST, another DA protein, has been associated with "conception rate" [81]. Increased FST mRNA levels have been observed in mature oocytes, while decreased levels have been associated with oocyte arrest in cattle [179]. Serpine-2 is associated with fertilization rates in cattle [85]. It has been found to be differentially expressed in the granulosa cells of bovine ovaries [66]. Association of these DA proteins with reproductive trait QTLs seems to support their involvement with female fertility, which could be expected for proteins that are involved in the formation and function of the CL.

\section{Conclusions}

This study has provided a set of ovarian proteins that were found to have altered abundance levels as a result of CL activity, progesterone signaling, and puberty in Bos indicus heifers. Selective regulation of proteins involved in various metabolic pathways indicated their role in up-regulating overall steroidogenesis upon puberty. The reported proteins have enhanced our current understanding of pathways that are regulated in CL cells and therefore contribute to progesterone signaling, with implications for oocyte maturation, puberty, and subsequent fertility. Some DA proteins are coded by genes in QTLs for female reproductive traits and can be further scrutinized in the search for causative mutations.

Supplementary Materials: The following are available online at http://www.mdpi.com/2073-4425/10/11/923/s1, Table S1: Total differentially expressed proteins in pre- versus post-pubertal Brahman heifers, Table S2: Pathways and differentially abundant proteins in post-pubertal heifers compared to pre-pubertal heifers involved in ovarian activities at puberty.

Author Contributions: Conceptualization, M.R.S.F. and S.S.M.; methodology, G.A.B.-H., M.G.T., and M.R.S.F.; software, M.S.T., B.L.S., and L.Y.L.; formal analysis, M.S.T.; investigation, M.S.T. and M.R.S.F.; resources, S.S.M. and M.R.S.F.; data curation, M.S.T. and L.T.N.; writing - original draft preparation, M.S.T.; writing-review and editing, M.S.T., M.G.T., and M.R.S.F.; supervision, M.R.S.F.; project administration, M.R.S.F., S.S.M., and G.A.B.-H.; funding acquisition, M.R.S.F. and S.S.M.

Funding: The project was funded by the University of Queensland, which provided a start-up grant to Stephen S. Moore. Muhammad S. Tahir received a scholarship from the University of Queensland and a top-up scholarship from The Commonwealth Scientific and Industrial Research Organization-Agriculture and Food Science.

Acknowledgments: George E. Seidel, Animal Reproduction and Biotechnology lab., Colorado State University, USA.

Conflicts of Interest: The authors declare no conflict of interest.

\section{References}

1. Mann, G.; Lamming, G. The Influence of Progesterone During Early Pregnancy in Cattle. Reprod. Domest. Anim. 1999, 34, 269-274. [CrossRef] 
2. Chenoweth, P. Aspects of reproduction in female Bos indicus cattle: A review. Aust. Vet. J. 1994, 71, $422-426$. [CrossRef] [PubMed]

3. Johnston, D.J.; Barwick, S.A.; Corbet, N.J.; Fordyce, G.; Holroyd, R.G.; Williams, P.J.; Burrow, H.M.; Corbet, N. Genetics of heifer puberty in two tropical beef genotypes in northern Australia and associations with heiferand steer-production traits. Anim. Prod. Sci. 2009, 49, 399-412. [CrossRef]

4. Short, R.E.; Staigmiller, R.B.; Bellows, R.A.; Greer, R.C. Breeding heifers at one year of age: Biological and economic considerations. In Factors Affecting Calf Crop; CRC: Boca Raton, FL, USA, 1994; pp. 55-68.

5. Short, R.E.; Bellows, R.A. Relationships among Weight Gains, Age at Puberty and Reproductive Performance in Heifers. J. Anim. Sci. 1971, 32, 127-131. [CrossRef]

6. Teleni, E.; Boniface, A.N.; Sutherland, S.; Entwistle, K.W. The effect of liveweight loss on ovarian activity in Bos indicus cattle [feed requirements]. [Conference paper]; In Proceedings of the Nutrition Society of Australia; James Cook University (Australia): Douglas, QLD, Australia, 1988.

7. McGowan ${ }^{1}$, M.R.; Holroyd, R.G. Reproductive inefficiencies and opportunities in dairy and beef cattle in Australia. Proc. Aust. Soc. Anim. Prod. 2008, 27.

8. Day, M.L.; Nogueira, G.P. Management of age at puberty in beef heifers to optimize efficiency of beef production. Anim. Front. 2013, 3, 6-11. [CrossRef]

9. Fortes, M.R.; DeAtley, K.L.; Lehnert, S.A.; Burns, B.M.; Reverter, A.; Hawken, R.J.; Boe-Hansen, G.; Moore, S.S.; Thomas, M.G. Genomic regions associated with fertility traits in male and female cattle: Advances from microsatellites to high-density chips and beyond. Anim. Reprod. Sci. 2013, 141, 1-19. [CrossRef] [PubMed]

10. Hyeong, K.-E.; Iqbal, A.; Kim, J.-J. A Genome Wide Association Study on Age at First Calving Using High Density Single Nucleotide Polymorphism Chips in Hanwoo (Bos tauruscoreanae). Asian Australas. J. Anim. Sci. 2014, 27, 1406-1410. [CrossRef] [PubMed]

11. Atkins, J.A.; Pohler, K.G.; Smith, M.F. Physiology and Endocrinology of Puberty in Heifers. Vet. Clin. N. Am. Food Anim. Pract. 2013, 29, 479-492. [CrossRef] [PubMed]

12. Moran, C.; Quirke, J.F.; Roche, J.F. Puberty in heifers: A Review. Anim. Reprod. Sci. 1989, 18, 167-182. [CrossRef]

13. Day, M.L.; Vanecek, J.; Illnerová, H. Endocrine mechanisms of puberty in heifers. Role of hypothalamopituitary estradiol receptors in the negative feedback of estradiol on luteinizing hormone secretion. Biol. Reprod. 1987, 37, 1054-1065. [CrossRef] [PubMed]

14. Smith, M.F.; Geisert, R.D.; Parrish, J.J. Reproduction in domestic ruminants during the past 50 yr: Discovery to application. J. Anim. Sci. 2018, 96, 2952-2970. [CrossRef] [PubMed]

15. McNatty, K.P.; Heath, D.A.; Henderson, K.M.; Lun, S.; Hurst, P.R.; Ellis, L.M.; Montgomery, G.W.; Morrison, L.; Thurley, D.C. Some aspects of thecal and granulosa cell function during follicular development in the bovine ovary. Reproduction 1984, 72, 39-53. [CrossRef] [PubMed]

16. Niswender, G.D.; Juengel, J.L.; Silva, P.J.; Rollyson, M.K.; McIntush, E.W. Mechanisms controlling the function and life span of the corpus luteum. Physiol. Rev. 2000, 80, 1-29. [CrossRef] [PubMed]

17. Lonergan, P. Influence of progesterone on oocyte quality and embryo development in cows. Theriogenology 2011, 76, 1594-1601. [CrossRef] [PubMed]

18. Lonergan, P.; Fair, T. Maturation of Oocytes in Vitro. Annu. Rev. Anim. Biosci. 2016, 4, 255-268. [CrossRef] [PubMed]

19. Hyttel, P.; Fair, T.; Callesen, H.; Greve, T. Oocyte growth, capacitation and final maturation in cattle. Theriogenology 1997, 47, 23-32. [CrossRef]

20. Kotsuji, F.; Kubo, M.; Tominaga, T. Effect of interactions between granulosa and thecal cells on meiotic arrest in bovine oocytes. Reproduction 1994, 100, 151-156. [CrossRef] [PubMed]

21. Park, J.-Y.; Su, Y.-Q.; Ariga, M.; Law, E.; Jin, S.-L.C.; Conti, M. EGF-Like Growth Factors as Mediators of LH Action in the Ovulatory Follicle. Science 2004, 303, 682-684. [CrossRef] [PubMed]

22. Bevers, M.; Dieleman, S.; Hurk, R.V.D.; Izadyar, F. Regulation and modulation of oocyte maturation in the bovine. Theriogenology 1997, 47, 13-22. [CrossRef]

23. Ben-Yehoshua, L.J.; Lewellyn, A.L.; Thomas, P.; Maller, J.L. The Role of Xenopus Membrane Progesterone Receptor $\beta$ in Mediating the Effect of Progesterone on Oocyte Maturation. Mol. Endocrinol. 2007, 21, 664-673. [CrossRef] [PubMed]

24. Haccard, O.; Jessus, C. Oocyte Maturation, Mos and Cyclins-A Matter of Synthesis: Two Functionally Redundant Ways to Induce Meiotic Maturation. Cell Cycle 2006, 5, 1152-1159. [CrossRef] [PubMed] 
25. Schumacher, M.; Robert, F. Progesterone: Synthesis, Metabolism, Mechanismsof Action, and Effectsinthe Nervous System. Overview 2002, 3, 683-745.

26. Fukui, Y.; Ono, H. Effects of sera, hormones and granulosa cells added to culture medium for in-vitro maturation, fertilization, cleavage and development of bovine oocytes. Reproduction 1989, 86, 501-506. [CrossRef] [PubMed]

27. Barros, C.M.; Satrapa, R.A.; Castilho, A.C.S.; Fontes, P.K.; Razza, E.M.; Ereno, R.L.; Nogueira, F.G.N. Effect of superstimulatory treatments on the expression of genes related to ovulatory capacity, oocyte competence and embryo development in cattle. Reprod. Fertil. Dev. 2012, 25, 17-25. [CrossRef] [PubMed]

28. Weller, M.M.D.A.; Fortes, M.R.S.; Porto-Neto, L.R.; Kelly, M.; Venus, B.; Kidd, L.; do Rego, J.P.A.; Edwards, S.; Boe-Hansen, G.G.; Piper, E.; et al. Candidate Gene Expression in Bos indicus Ovarian Tissues: Prepubertal and Postpubertal Heifers in Diestrus. Front. Vet. Sci. 2016, 3, 94. [CrossRef] [PubMed]

29. Nguyen, L.T.; Reverter, A.; Cánovas, A.; Venus, B.; Islas-Trejo, A.; Porto-Neto, L.R.; Lehnert, S.A.; Medrano, J.F.; Moore, S.S.; Fortes, M.R.S. Global differential gene expression in the pituitary gland and the ovaries of preand postpubertal Brahman heifers. J. Anim. Sci. 2017, 95, 599. [CrossRef] [PubMed]

30. Fortes, M.R.S.; Nguyen, L.T.; Weller, M.M.D.C.A.; Cánovas, A.; Islas-Trejo, A.; Porto-Neto, L.R.; Reverter, A.; Lehnert, S.A.; Boe-Hansen, G.B.; Thomas, M.G.; et al. Transcriptome analyses identify five transcription factors differentially expressed in the hypothalamus of post- versus prepubertal Brahman heifers1. J. Anim. Sci. 2016, 94, 3693-3702. [CrossRef] [PubMed]

31. Fortes, M.R.S.; Zacchi, L.F.; Nguyen, L.T.; Raidan, F.; Weller, M.M.D.C.A.; Choo, J.J.Y.; Reverter, A.; Rego, J.P.A.; Boe-Hansen, G.B.; Porto-Neto, L.R. Pre- and post-puberty expression of genes and proteins in the uterus of Bos indicus heifers: The luteal phase effect post-puberty. Anim. Genet. 2018, 49, 539-549. [CrossRef] [PubMed]

32. DeAtley, K.L.; Colgrave, M.L.; Cánovas, A.; Wijffels, G.; Ashley, R.L.; Silver, G.A.; Rincon, G.; Medrano, J.F.; Islas-Trejo, A.; Fortes, M.R.S.; et al. Neuropeptidome of the Hypothalamus and Pituitary Gland of Indicine $\mathrm{x}$ Taurine Heifers: Evidence of Differential Neuropeptide Processing in the Pituitary Gland before and after Puberty. J. Proteome Res. 2018, 17, 1852-1865. [CrossRef] [PubMed]

33. Xu, Y.; Bailey, U.-M.; Schulz, B. Automated measurement of site-specific N -glycosylation occupancy with SWATH-MS. Proteomics 2015, 15, 2177-2186. [CrossRef] [PubMed]

34. Gillet, L.C.; Navarro, P.; Tate, S.; Röst, H.; Selevsek, N.; Reiter, L.; Bonner, R.; Aebersold, R. Targeted data extraction of the MS/MS spectra generated by data-independent acquisition: A new concept for consistent and accurate proteome analysis. Mol. Cell. Proteom. 2012, 11, O111.016717. [CrossRef] [PubMed]

35. Kerr, E.D.; Phung, T.K.; Caboche, C.H.; Fox, G.P.; Platz, G.J.; Schulz, B.L. The intrinsic and regulated proteomes of barley seeds in response to fungal infection. Anal. Biochem. 2019, 580, 30-35. [CrossRef] [PubMed]

36. Enculescu, C.; Kerr, E.D.; Yeo, K.Y.B.; Schenk, G.; Fortes, M.R.S.; Schulz, B.L. Proteomics Reveals Profound Metabolic Changes in the Alcohol Use Disorder Brain. ACS Chem. Neurosci. 2019, 10, 2364-2373. [CrossRef] [PubMed]

37. Choi, M.; Chang, C.-Y.; Clough, T.; Broudy, D.; Killeen, T.; MacLean, B.; Vitek, O. MSstats: An R package for statistical analysis of quantitative mass spectrometry-based proteomic experiments. Bioinformatics 2014, 30, 2524-2526. [CrossRef] [PubMed]

38. Huangda, W.; Sherman, B.T.; Lempicki, R.A. Systematic and integrative analysis of large gene lists using DAVID bioinformatics resources. Nat. Protoc. 2009, 4, 44-57. [CrossRef] [PubMed]

39. Szklarczyk, D.; Andrea, F.; Stefan, W.; Kristoffer, F.; Davide, H.; Jaime, H.C.; Milan, S.; Alexander, R.; Alberto, S.; Kalliopi, P.T.; et al. STRING v10: Protein-protein interaction networks, integrated over the tree of life. Nucleic Acids Res. 2015, 43, D447-D452. [CrossRef] [PubMed]

40. Animal QTLdb. 2018. Available online: https://www.animalgenome.org/cgi-bin/QTLdb/BT/index (accessed on 12 November 2019).

41. Murray, R.K.; Granner, D.K.; Mayes, P.; Rodwell, V. Harper's Illustrated Biochemistry; McGraw-Hill: New York, NY, USA, 2009; Volume 28.

42. Miller, W.L. Minireview: Regulation of Steroidogenesis by Electron Transfer. Endocrinology 2005, 146, 2544-2550. [CrossRef] [PubMed]

43. Miller, W.L. Steroid hormone synthesis in mitochondria. Mol. Cell. Endocrinol. 2013, 379, 62-73. [CrossRef] [PubMed] 
44. Russell, D.W. Cholesterol biosynthesis and metabolism. Cardiovasc. Drugs Ther. 1992, 6, 103-110. [CrossRef] [PubMed]

45. Christianson, D.W. Structural Biology and Chemistry of the Terpenoid Cyclases. Chem. Rev. 2006, 106, 3412-3442. [CrossRef] [PubMed]

46. Buzanskas, M.E.; Grossi, D.A.; Ventura, R.V.; Chud, T.C.S.; Urbinati, I.; Meirelles, S.L.C.; Mokry, F.B.; Schenkel, F.S.; Regitano, L.C.A.; Munari, D.P. Genome-wide association study on long-yearling scrotal circumference in Canchim cattle. In Embrapa Pecuária Sudeste-Artigo em Anais de Congresso (ALICE); Amarican Society of Animal Science: Champaign, IL, USA, 2014.

47. Aguilera-Méndez, A.; Cynthia, F.L.; Isabel, I.G.; Cristina, F.M. The chemistry and biochemistry of niacin(B3). In B Vitamins and Folate; Royal Society of Chemistry: London, UK, 2012; pp. 108-126.

48. Wakil, S.J. Fatty acid synthase, a proficient multifunctional enzyme. Biochemistry 1989, 28, 4523-4530. [CrossRef] [PubMed]

49. Guay, C.; Madiraju, S.R.M.; Aumais, A.; Joly, É.; Prentki, M.; Madiraju, S.R.M. A Role for ATP-Citrate Lyase, Malic Enzyme, and Pyruvate/Citrate Cycling in Glucose-induced Insulin Secretion. J. Biol. Chem. 2007, 282, 35657-35665. [CrossRef] [PubMed]

50. Itami, N.; Kawahara-Miki, R.; Kawana, H.; Endo, M.; Kuwayama, T.; Iwata, H. Age-associated changes in bovine oocytes and granulosa cell complexes collected from early antral follicles. J. Assist. Reprod. Genet. 2014, 31, 1079-1088. [CrossRef] [PubMed]

51. Roucher-Boulez, F.; Mallet-Moták, D.; Samara-Boustani, D.; Jilani, H.; Ladjouze, A.; Souchon, P.F.; Simon, D.; Nivot, S.; Heinrichs, C.; Ronze, M.; et al. NNT mutations: A cause of primary adrenal insufficiency, oxidative stress and extra-adrenal defects. Eur. J. Endocrinol. 2016, 175, 73-84. [CrossRef] [PubMed]

52. Payton, R.R.; Rispoli, L.A.; Nagle, K.A.; Gondro, C.; Saxton, A.M.; Voy, B.H.; Edwards, J.L. Mitochondrial-related consequences of heat stress exposure during bovine oocyte maturation persist in early embryo development. J. Reprod. Dev. 2018, 64, 243-251. [CrossRef] [PubMed]

53. Rone, M.B.; Midzak, A.S.; Issop, L.; Rammouz, G.; Jagannathan, S.; Fan, J.; Ye, X.; Blonder, J.; Veenstra, T.; Papadopoulos, V. Identification of a Dynamic Mitochondrial Protein Complex Driving Cholesterol Import, Trafficking, and Metabolism to Steroid Hormones. Mol. Endocrinol. 2012, 26, 1868-1882. [CrossRef] [PubMed]

54. Craig, Z.R.; Singh, J.; Gupta, R.K.; Flaws, J.A. Co-treatment of mouse antral follicles with $17 \beta$-estradiol interferes with mono-2-ethylhexyl phthalate (MEHP)-induced atresia and altered apoptosis gene expression. Reprod. Toxicol. 2014, 45, 45-51. [CrossRef] [PubMed]

55. Muramatsu, H.; Zou, P.; Kurosawa, N.; Ichihara-Tanaka, K.; Maruyama, K.; Inoh, K.; Sakai, T.; Chen, L.; Sato, M.; Muramatsu, T. Female infertility in mice deficient in midkine and pleiotrophin, which form a distinct family of growth factors. Genes Cells 2006, 11, 1405-1417. [CrossRef] [PubMed]

56. Salhab, M.; Tosca, L.; Cabau, C.; Papillier, P.; Perreau, C.; Dupont, J.; Mermillod, P.; Uzbekova, S. Kinetics of gene expression and signaling in bovine cumulus cells throughout IVM in different mediums in relation to oocyte developmental competence, cumulus apoptosis and progesterone secretion. Theriogenology 2011, 75, 90-104. [CrossRef] [PubMed]

57. Aoyama, M.; Shiraishi, A.; Matsubara, S.; Horie, K.; Osugi, T.; Kawada, T.; Yasuda, K.; Satake, H. Identification of a New Theca/Interstitial Cell-Specific Gene and Its Biological Role in Growth of Mouse Ovarian Follicles at the Gonadotropin-Independent Stage. Front. Endocrinol. 2019, 10, 553. [CrossRef] [PubMed]

58. Meldi, K.M.; Gaconnet, G.A.; Mayo, K.E. DNA methylation and histone modifications are associated with repression of the inhibin $\alpha$ promoter in the rat corpus luteum. Endocrinol. 2012, 153, 4905-4917. [CrossRef] [PubMed]

59. Gohin, M.; Fournier, E.; Dufort, I.; Sirard, M.-A. Discovery, identification and sequence analysis of RNAs selected for very short or long poly A tail in immature bovine oocytes. Mol. Hum. Reprod. 2013, 20, 127-138. [CrossRef] [PubMed]

60. Ellederová, Z.; Cais, O.; Susor, A.; Uhlírová, K.; Kovárová, H.; Jelínková, L.; Tomek, W.; Kubelka, M. ERK1/2 map kinase metabolic pathway is responsible for phosphorylation of translation initiation factor eIF4E during in vitro maturation of pig oocytes. Mol. Reprod. Dev. 2008, 75, 309-317.

61. Mondal, M.; Schilling, M.; Folger, J.; Steibel, J.P.; Buchnick, H.; Zalman, Y.; Ireland, J.J.; Meidan, R.; Smith, G.W. Deciphering the luteal transcriptome: Potential. Physiol. Genomics 2013, 45, 1095-1108. 
62. Hamel, M.; Dufort, I.; Robert, C.; Gravel, C.; Leveille, M.-C.; Leader, A.; Sirard, M.-A. Identification of differentially expressed markers in human follicular cells associated with competent oocytes. Hum. Reprod. 2008, 23, 1118-1127. [CrossRef] [PubMed]

63. Dominguez, M.A.; Cho, N.; Zhang, B.; Neal, M.S.; Foster, W.G. Brain-derived neurotrophic factor expression in granulosa lutein cells. Reprod. Biomed. Online 2011, 22, 17-24. [CrossRef] [PubMed]

64. Cibelli, J.B.; Iager, A.E.; Otu, H.H. Genes Differentially Expressed by Cumulus Cells and Assays Using Sameto Identify Pregnancy Competent Oocytes. U.S. Patent 14/351,750, 2 October 2014.

65. Shao, L.; Chian, R.-C.; Xu, Y.; Yan, Z.; Zhang, Y.; Gao, C.; Gao, L.; Liu, J.; Cui, Y. Genomic expression profiles in cumulus cells derived from germinal vesicle and MII mouse oocytes. Reprod. Fertil. Dev. 2016, 28, 1798-1809. [CrossRef] [PubMed]

66. Bédard;" J.; Brûlé, S.; Price, C.A.; Silversides, D.W.; Lussier, J.G. Serine protease inhibitor-E2(SERPINE2) is differentially expressed in granulosa cells of dominant follicle in cattle. Mol. Reprod. Dev. Inc. Gamete Res. 2003, 64, 152-165.

67. Ducolomb, Y.; González-Márquez, H.; Fierro, R.; Jiménez, I.; Casas, E.; Flores, D.; Bonilla, E.; Salazar, Z.; Betancourt, M. Effect of porcine follicular fluid proteins and peptides on oocyte maturation and their subsequent effect on in vitro fertilization. Theriogenology 2013, 79, 896-904. [CrossRef] [PubMed]

68. Wang, L.; Xu, Z.; Khawar, M.B.; Liu, C.; Li, W. The histone codes for meiosis. Reproduction 2017, 154, R65. [CrossRef] [PubMed]

69. Griffin, D.K.; Ellis, P.J.; Dunmore, B.; Bauer., J.; Abel., M.H.; Affara, N.A. Transcriptional Profiling of Luteinizing Hormone Receptor-Deficient Mice Before and after Testosterone Treatment Provides Insight into the Hormonal Control of Postnatal Testicular Development and Leydig Cell Differentiation. Biol. Reprod. 2010, 82, 1139-1150. [CrossRef] [PubMed]

70. Yamane, J. The Proteolytic Action of Mammalian Spermatozoa and Its Bearing upon the Second Maturation Division of Ova. Cytologia 1930, 1, 394-403. [CrossRef]

71. Dunning, K.R.; Watson, L.N.; Zhang, V.J.; Brown, H.M.; Kaczmarek, A.K.; Robker, R.L.; Russell, D.L. Activation of Mouse Cumulus-Oocyte Complex Maturation In Vitro Through EGF-Like Activity of Versican1. Biol. Reprod. 2015, 92, 116. [CrossRef] [PubMed]

72. Irving-Rodgers, H.F.; Rodgers, R.J. Extracellular matrix in ovarian follicular development and disease. Cell Tissue Res. 2005, 322, 89-98. [CrossRef] [PubMed]

73. Budna, J.; Celichowski, P.; Bryja, A.; Dyszkiewicz-Konwińska, M.; Jeseta, M.; Bukowska, D.; Antosik, P.; Brüssow, K.P.; Bruska, M.; Nowicki, M.; et al. Significant Down-Regulation of "Biological Adhesion" Genes in Porcine Oocytes after IVM. Int. J. Mol. Sci. 2017, 18, 2685. [CrossRef] [PubMed]

74. Niu, H.-R.; Zi, X.-D.; Xiao, X.; Xiong, X.-R.; Zhong, J.-C.; Li, J.; Wang, L.; Wang, Y. Cloning of cDNAs for H1F0, TOP1, CLTA and CDK1 and the effects of cryopreservation on the expression of their mRNA transcripts in yak (Bos grunniens) oocytes. Cryobiolgy 2014, 69, 55-60. [CrossRef] [PubMed]

75. Kayani, A.R.; Glister, C.; Knight, P.G. Evidence for an inhibitory role of bone morphogenetic protein(s) in the follicular-luteal transition in cattle. Reproduction 2009, 137, 67-78. [CrossRef] [PubMed]

76. Adona, P.R.; Leal, C.L.; Biase, F.H.; De Bem, T.H.; Mesquita, L.G.; Meirelles, F.V.; Ferraz, A.L.; Furlan, L.R.; Monzani, P.S.; Guemra, S. In vitro maturation alters gene expression in bovine oocytes. Zygote 2016, 24, 624-633. [CrossRef] [PubMed]

77. Assou, S.; Haouzi, D.; Dechaud, H.; Gala, A.; Ferrieres, A.; Hamamah, S. Comparative Gene Expression Profiling in Human Cumulus Cells according to Ovarian Gonadotropin Treatments. BioMed. Res. Int. 2013, 2013, 1-13. [CrossRef] [PubMed]

78. Powell, M.D.; Manandhar, G.; Spate, L.; Sutovsky, M.; Zimmerman, S.; Sachdev, S.C.; Hannink, M.; Prather, R.S.; Sutovsky, P. Discovery of putative oocyte quality markers by comparative ExacTag proteomics. Proteom. Clin. Appl. 2010, 4, 337-351. [CrossRef] [PubMed]

79. Kolbehdari, D.; Wang, Z.; Grant, J.; Murdoch, B.; Prasad, A.; Xiu, Z.; Marquès, E.; Stothard, P.; Moore, S. A Whole-Genome Scan to Map Quantitative Trait Loci for Conformation and Functional Traits in Canadian Holstein Bulls. J. Dairy Sci. 2008, 91, 2844-2856. [CrossRef] [PubMed]

80. Dikmen, S.; Wang, X.-Z.; Ortega, M.; Cole, J.; Null, D.; Hansen, P. Single nucleotide polymorphisms associated with thermoregulation in lactating dairy cows exposed to heat stress. J. Anim. Breed. Genet. 2015, 132, 409-419. [CrossRef] [PubMed] 
81. Ortega, M.S.; Denicol, A.C.; Cole, J.B.; Null, D.J.; Hansen, P.J.; Cole, J. Use of single nucleotide polymorphisms in candidate genes associated with daughter pregnancy rate for prediction of genetic merit for reproduction in Holstein cows. Anim. Genet. 2016, 47, 288-297. [CrossRef] [PubMed]

82. Cochran, S.D.; Cole, J.B.; Null, D.J.; Hansen, P.J. Discovery of single nucleotide polymorphisms in candidate genes associated with fertility and production traits in Holstein cattle. BMC Genet. 2013, 14, 49. [CrossRef] [PubMed]

83. Collis, E.; Fortes, M.R.; Zhang, Y.; Tier, B.; Schutt, K.; Barendse, W.; Hawken, R. Genetic variants affecting meat and milk production traits appear to have effects on reproduction traits in cattle. Anim. Genet. 2012, 43, 442-446. [CrossRef] [PubMed]

84. Bongiorni, S.; Mancini, G.; Chillemi, G.; Pariset, L.; Valentini, A. Identification of a Short Region on Chromosome 6 Affecting Direct Calving Ease in Piedmontese Cattle Breed. PLoS ONE 2012, 7, e50137. [CrossRef] [PubMed]

85. Cochran, S.D.; Cole, J.B.; Null, D.J.; Hansen, P.J. Single Nucleotide Polymorphisms in Candidate Genes Associated with Fertilizing Ability of Sperm and Subsequent Embryonic Development in Cattle1. Biol. Reprod. 2013, 89, 69. [CrossRef] [PubMed]

86. Romano, M.; Barnabe, V.; Kastelic, J.; De Oliveira, C.; Romano, R.M.; Barnabe, V. Follicular Dynamics in Heifers during Pre-pubertal and Pubertal Period Kept under Two Levels of Dietary Energy Intake. Reprod. Domest. Anim. 2007, 42, 616-622. [CrossRef] [PubMed]

87. Binelli, M.; Thatcher, W.; Mattos, R.; Baruselli, P. Antiluteolytic strategies to improve fertility in cattle. Theriogenology 2001, 56, 1451-1463. [CrossRef]

88. Rekawiecki, R.; Kowalik, M.K.; Slonina, D.; Kotwica, J. Regulation of progesterone synthesis and action in bovine corpus luteum. J. Physiol. Pharmacol. Off. J. Pol. Physiol. Soc. 2008, 59, 75-89.

89. Steeves, T.; Gardner, D. Metabolism of glucose, pyruvate, and glutamine during the maturation of oocytes derived from pre-pubertal and adult cows. Mol. Reprod. Dev. 1999, 54, 92-101. [CrossRef]

90. Hales, D.B.; Allen, J.A.; Shankara, T.; Janus, P.; Buck, S.; Diemer, T. Mitochondrial Function in Leydig Cell Steroidogenesis. Ann. N. Y. Acad. Sci. 2005, 1061, 120-134. [CrossRef] [PubMed]

91. Valsangkar, D.; Downs, S.M. A Requirement for Fatty Acid Oxidation in the Hormone-Induced Meiotic Maturation of Mouse Oocytes. Biol. Reprod. 2013, 89, 43. [CrossRef] [PubMed]

92. Labrecque, R.; Lodde, V.; Dieci, C.; Tessaro, I.; Luciano, A.M.; Sirard, M.A. Chromatin remodelling and histone mRNA accumulation in bovine germinal vesicle oocytes. Mol. Reprod. Dev. 2015, 82, 450-462. [CrossRef] [PubMed]

93. Vassalli, J.-D.; Stutz, A. Translational Control: Awakening dormant mRNAs. Curr. Biol. 1995, 5, 476-479. [CrossRef]

94. Angelov, D.; Molla, A.; Perche, P.-Y.; Hans, F.; Côté, J.; Khochbin, S.; Bouvet, P.; Dimitrov, S. The Histone Variant MacroH2A Interferes with Transcription Factor Binding and SWI/SNF Nucleosome Remodeling. Mol. Cell 2003, 11, 1033-1041. [CrossRef]

95. Yang, J.; Everett, A.D. Hepatoma derived growth factor binds DNA through the N-terminal PWWP domain. BMC Mol. Biol. 2007, 8, 101. [CrossRef] [PubMed]

96. Dutta, B.; Ren, Y.; Hao, P.; Sim, K.H.; Cheow, E.; Adav, S.S.; Tam, J.P.; Sze, S.K. Profiling of the Chromatin-associated Proteome Identifies HP1BP3 as a Novel Regulator of Cell Cycle Progression. Mol. Cell. Proteom. 2014, 13, 2183-2197. [CrossRef] [PubMed]

97. Rath, N.; Wang, Z.; Lu, M.M.; Morrisey, E.E. LMCD1/Dyxin Is a Novel Transcriptional Cofactor That Restricts GATA6 Function by Inhibiting DNA Binding. Mol. Cell. Biol. 2005, 25, 8864-8873. [CrossRef] [PubMed]

98. Magoffin, D.A. Regulation of differentiated functions in ovarian theca cells. In Seminars in Reproductive Endocrinology; Thieme Medical Publishers, Inc.: New York, NY, USA, 1991.

99. Kandil, O.; Ghanem, N.; Abdoon, A.; Hölker, M.; Phatsara, C.; Schellander, K.; Tesfaye, D.; Kandil, O. Transcriptional Analysis of Buffalo (Bubalusbubalis) Oocytes DuringInVitroMaturation Using Bovine cDNA Microarray. Reprod. Domest. Anim. 2010, 45, 63-74. [CrossRef] [PubMed]

100. Van Der Velden, A.W.; Thomas, A.A. The role of the 5' untranslated region of an mRNA in translation regulation during development. Int. J. Biochem. Cell Biol. 1999, 31, 87-106. [CrossRef]

101. Rogers, G.W., Jr.; Richter, N.J.; Lima, W.F.; Merrick, W.C. Modulation of the helicase activity of eIF4A by eIF4B, eIF4H, and eIF4F. J. Biol. Chem. 2001, 276, 30914-30922. [CrossRef] [PubMed] 
102. Shirasuna, K.; Nitta, A.; Sineenard, J.; Shimizu, T.; Bollwein, H.; Miyamoto, A. Vascular and immune regulation of corpus luteum development, maintenance, and regression in the cow. Domest. Anim. Endocrinol. 2012, 43, 198-211. [CrossRef] [PubMed]

103. Georgiou, A.; Gil, M.; Almiñana, C.; Cuello, C.; Vazquez, J.M.; Roca, J.; Martinez, E.; Fazeli, A. Effects of Complement Component 3 Derivatives on Pig Oocyte Maturation, Fertilization and Early Embryo Development In Vitro. Reprod. Domest. Anim. 2011, 46, 1017-1021. [CrossRef] [PubMed]

104. Yoo, S.W.; Bolbot, T.; Koulova, A.; Sneeringer, R.; Humm, K.; Dagon, Y.; Usheva, A. Complement factors are secreted in human follicular fluid by granulosa cells and are possible oocyte maturation factors. J. Obstet. Gynaecol. Res. 2013, 39, 522-527. [CrossRef] [PubMed]

105. Albertini, D.; Combelles, C.; Benecchi, E.; Carabatsos, M. Cellular basis for paracrine regulation of ovarian follicle development. Reproduction 2001, 121, 647-653. [CrossRef] [PubMed]

106. Baddela, V.S.; Koczan, D.; Viergutz, T.; Vernunft, A.; Vanselow, J. Global gene expression analysis indicates that small luteal cells are involved in extracellular matrix modulation and immune cell recruitment in the bovine corpus luteum. Mol. Cell. Endocrinol. 2018, 474, 201-213. [CrossRef] [PubMed]

107. Irving-Rodgers, H.F.; Roger, J.; Luck, M.R.; Rodgers, R.J. Extracellular matrix of the corpus luteum. In Seminars in Reproductive Medicine; Thieme Medical Publishers, Inc.: New York, NY, USA, 2006.

108. Virant-Klun, I.; Leicht, S.; Hughes, C.; Krijgsveld, J. Identification of Maturation-Specific Proteins by Single-Cell Proteomics of Human Oocytes. Mol. Cell. Proteom. 2016, 15, 2616-2627. [CrossRef] [PubMed]

109. Li, S.-H.; Lin, M.-H.; Hwu, Y.-M.; Lu, C.-H.; Yeh, L.-Y.; Chen, Y.-J.; Lee, R.K.-K. Correlation of cumulus gene expression of GJA1, PRSS35, PTX3, and SERPINE2 with oocyte maturation, fertilization, and embryo development. Reprod. Biol. Endocrinol. 2015, 13, 93. [CrossRef] [PubMed]

110. Hatzirodos, N.; Hummitzsch, K.; Irving-Rodgers, H.F.; Rodgers, R.J. Transcriptome profiling of the theca interna in transition from small to large antral ovarian follicles. PLoS ONE 2014, 9, e97489. [CrossRef] [PubMed]

111. Murphy, B.D. Models of Luteinization. Biol. Reprod. 2000, 63, 2-11. [CrossRef] [PubMed]

112. Lourim, D.; Kempf, A.; Krohne, G. Characterization and quantitation of three B-type lamins in Xenopus oocytes and eggs: Increase of lamin LI protein synthesis during meiotic maturation. J. Cell Sci. 1996, 109, 1775-1785. [PubMed]

113. Shim, C.; Lee, S.G.; Song, W.K.; Lee, C.S.; Lee, K.-K.; Kim, K. Laminin chain-specific gene expression during mouse oocyte maturation. Mol. Reprod. Dev. 1997, 48, 185-193. [CrossRef]

114. Robert, K.; Murray, D.K.G.; Peter, A.; Victor, W. Harper's Illustrated Biochemistry, 26th ed.; McGraw-Hill Companies, Inc.: New York, NY, USA, 2003; pp. 137-142.

115. Zhang, S.; Hulver, M.W.; McMillan, R.P.; A Cline, M.; Gilbert, E.R. The pivotal role of pyruvate dehydrogenase kinases in metabolic flexibility. Nutr. Metab. 2014, 11, 10. [CrossRef] [PubMed]

116. Ke, J.; Behal, R.H.; Back, S.L.; Nikolau, B.J.; Wurtele, E.S.; Oliver, D.J. The Role of Pyruvate Dehydrogenase and Acetyl-Coenzyme A Synthetase in Fatty Acid Synthesis in Developing Arabidopsis Seeds. Plant Physiol. 2000, 123, 497-508. [CrossRef] [PubMed]

117. Schulz, H. Beta oxidation of fatty acids. Biochim. Biophys. Acta Lipids Lipid Metab. 1991, 1081, $109-120$. [CrossRef]

118. Wohlt, J.E.; Clark, J.H.; Derrig, R.G.; Davis, C.L. Valine, Leucine, and Isoleucine Metabolism by Lactating Bovine Mammary Tissue. J. Dairy Sci. 1977, 60, 1875-1882. [CrossRef]

119. Salati, L.M.; Amir-Ahmady, B. Dietary regulation of expression of glucose-6-phosphate dehydrogenase. Annu. Rev. Nutr. 2001, 21, 121-140. [CrossRef] [PubMed]

120. Tabas, I. Consequences of cellular cholesterol accumulation: Basic concepts and physiological implications. J. Clin. Investig. 2002, 110, 905-911. [CrossRef] [PubMed]

121. Hara, H.; Yokoyama, S. Role of apolipoproteins in cholesterol efflux from macrophages to lipid microemulsion: Proposal of a putative model for the pre-.beta.-high-density lipoprotein pathway. Biochemistry 1992, 31, 2040-2046. [CrossRef] [PubMed]

122. Yano, K.; Ohkawa, R.; Sato, M.; Yoshimoto, A.; Ichimura, N.; Kameda, T.; Kubota, T.; Tozuka, M. Cholesterol Efflux Capacity of Apolipoprotein A-I Varies with the Extent of Differentiation and Foam Cell Formation of THP-1 Cells. J. Lipids 2016, 2016, 1-9. [CrossRef] [PubMed]

123. Yadav, R.; Petrunak, E.M.; Estrada, D.F.; Scott, E.E. Structural insights into the function of steroidogenic cytochrome P450 17A1. Mol. Cell. Endocrinol. 2017, 441, 68-75. [CrossRef] [PubMed] 
124. Ryan, K.J. Biochemistry of aromatase: Significance to female reproductive physiology. Cancer Res. 1982, 42, 3342-3344.

125. Salehnia, M.; Zavareh, S. The Effects of Progesterone on Oocyte Maturation and Embryo Development. Int. J. Fertil. Steril. 2013, 7, 74-81. [PubMed]

126. Luciano, A.M.; Lodde, V.; Franciosi, F.; Ceciliani, F.; Peluso, J.J. Progesterone receptor membrane component 1 expression and putative function in bovine oocyte maturation, fertilization, and early embryonic development. Reproduction 2010, 140, 663-672. [CrossRef] [PubMed]

127. Siqueira, L.C.; Barreta, M.H.; Gasperin, B.; Bohrer, R.; Santos, J.T.; Júnior, J.B.; Oliveira, J.F.; Gonçalves, P.B. Angiotensin II, progesterone, and prostaglandins are sequential steps in the pathway to bovine oocyte nuclear maturation. Theriogenology 2012, 77, 1779-1787. [CrossRef] [PubMed]

128. Davis, J.; May, J.; Keel, B. Mechanisms of hormone and growth factor action in the bovine corpus luteum. Theriogenology 1996, 45, 1351-1380. [CrossRef]

129. Priyanka, S.; Medhamurthy, R. Characterization of cAMP/PKA/CREB signaling cascade in the bonnet monkey corpus luteum: Expressions of inhibin- $\alpha$ and StAR during different functional status. Mol. Hum. Reprod. 2007, 13, 381-390. [CrossRef] [PubMed]

130. Aizen, J.; Pang, Y.; Harris, C.; Converse, A.; Zhu, Y.; Aguirre, M.A.; Thomas, P. Roles of progesterone receptor membrane component 1 and membrane progestin receptor alpha in regulation of zebrafish oocyte maturation. Gen. Comp. Endocrinol. 2018, 263, 51-61. [CrossRef] [PubMed]

131. Maller, J.L.; Krebs, E.G. Progesterone-stimulated meiotic cell division in Xenopus oocytes. Induction by regulatory subunit and inhibition by catalytic subunit of adenosine $3^{\prime}: 5^{\prime}$-monophosphate-dependent protein kinase. J. Biol. Chem. 1977, 252, 1712-1718.

132. Pace, M.C.; Thomas, P. Activation of a pertussis toxin-sensitive, inhibitory G-protein is necessary for steroid-mediated oocyte maturation in spotted seatrout. Dev. Biol. 2005, 285, 70-79. [CrossRef] [PubMed]

133. Nagahama, Y.; Yamashita, M. Regulation of oocyte maturation in fish. Dev. Growth Differ. 2008, 50, S195-S219. [CrossRef] [PubMed]

134. Karaiskou, A.; Dupré, A.; Haccard, O.; Jessus, C. From progesterone to active Cdc2 in Xenopus oocytes: A puzzling signalling pathway. Biol. Cell 2001, 93, 35-46. [CrossRef]

135. Shima, F.; Okada, T.; Kido, M.; Sen, H.; Tanaka, Y.; Tamada, M.; Hu, C.-D.; Yamawaki-Kataoka, Y.; Kariya, K.-I.; Kataoka, T. Association of Yeast Adenylyl Cyclase with Cyclase-Associated Protein CAP Forms a Second Ras-Binding Site Which Mediates Its Ras-Dependent Activation. Mol. Cell. Biol. 2000, 20, 26-33. [CrossRef] [PubMed]

136. Dzeja, P.; Terzic, A. Adenylate Kinase and AMP Signaling Networks: Metabolic Monitoring, Signal Communication and Body Energy Sensing. Int. J. Mol. Sci. 2009, 10, 1729-1772. [CrossRef] [PubMed]

137. Karteris, E.; Zervou, S.; Pang, Y.; Dong, J.; Hillhouse, E.W.; Randeva, H.S.; Thomas, P. Progesterone Signaling in Human Myometrium through Two Novel Membrane G Protein-Coupled Receptors: Potential Role in Functional Progesterone Withdrawal at Term. Mol. Endocrinol. 2006, 20, 1519-1534. [CrossRef] [PubMed]

138. Gilman, A.G. G Proteins: Transducers of Receptor-Generated Signals. Annu. Rev. Biochem. 1987, 56, 615-649. [CrossRef] [PubMed]

139. Chen, M.-S.; Ryan, C.E.; Piwnica-Worms, H. Chk1 Kinase Negatively Regulates Mitotic Function of Cdc25A Phosphatase through 14-3-3 Binding. Mol. Cell. Biol. 2003, 23, 7488-7497. [CrossRef] [PubMed]

140. Cann, K.L.; Hicks, G.G. Regulation of the cellular DNA double-strand break response. Biochem. Cell Biol. 2007, 85, 663-674. [CrossRef] [PubMed]

141. Schmitt, A.; Nebreda, A.R. Signalling pathways in oocyte meiotic maturation. J. Cell Sci. 2002, 115, $2457-2459$. [PubMed]

142. Talavera, F.; Chew, B. Comparative role of retinol, retinoic acid and $\beta$-carotene on progesterone secretion by pig corpus luteum in vitro. Reproduction 1988, 82, 611-615. [CrossRef] [PubMed]

143. Ikeda, S.; Kitagawa, M.; Imai, H.; Yamada, M. The roles of vitamin A for cytoplasmic maturation of bovine oocytes. J. Reprod. Dev. 2005, 51, 23-35. [CrossRef] [PubMed]

144. Gómez, E.; Royo, L.-J.; Duque, P.; Carneiro, G.; Hidalgo, C.; Goyache, F.; Lorenzo, P.L.; Alvarez, I.; Facal, N.; Díez, C. 9-cis-retinoic acid during in vitro maturation improves development of the bovine oocyte and increases midkine but not IGF-I expression in cumulus-granulosa cells. Mol. Reprod. Dev. 2003, 66, 247-255. [CrossRef] [PubMed]

145. Morriss-Kay, G.; Wardt, S. Retinoids and Mammalian Development. Adv. Clin. Chem. 1999, 188, 73-131. 
146. Lin, S. Regulation of ovarian function by the TGF-beta superfamily and follistatin. Reproduction 2003, 126, 133-148. [CrossRef] [PubMed]

147. Maris, P.; Blomme, A.; Palacios, A.P.; Costanza, B.; Bellahcène, A.; Bianchi, E.; Gofflot, S.; Drion, P.; Trombino, G.E.; Di Valentin, E.; et al. Asporin Is a Fibroblast-Derived TGF- $\beta 1$ Inhibitor and a Tumor Suppressor Associated with Good Prognosis in Breast Cancer. PLoS Med. 2015, 12, e1001871. [CrossRef] [PubMed]

148. Nakajima, M.; Kizawa, H.; Saitoh, M.; Kou, I.; Miyazono, K.; Ikegawa, S. Mechanisms for Asporin Function and Regulation in Articular Cartilage. J. Biol. Chem. 2007, 282, 32185-32192. [CrossRef] [PubMed]

149. Yamaguchi, Y.; Mann, D.M.; Ruoslahti, E. Negative regulation of transforming growth factor- $\beta$ by the proteoglycan decorin. Nature 1990, 346, 281-284. [CrossRef] [PubMed]

150. Knight, P.G.; Glister, C.; Knight, P. TGF- $\beta$ superfamily members and ovarian follicle development. Reproduction 2006, 132, 191-206. [CrossRef] [PubMed]

151. Miyamoto, A.; Okuda, K.; Schweigert, F.J.; Schams, D. Effects of basic fibroblast growth factor, transforming growth factor- $\beta$ and nerve growth factor on the secretory function of the bovine corpus luteum in vitro. J. Endocrinol. 1992, 135, 103-114. [CrossRef] [PubMed]

152. Hou, X.; Arvisais, E.W.; Jiang, C.; Chen, D.; Roy, S.K.; Pate, J.L.; Hansen, T.R.; Rueda, B.R.; Davis, J.S. Prostaglandin F2 $\alpha$ Stimulates the Expression and Secretion of Transforming Growth Factor B1 Via Induction of the Early Growth Response 1 Gene (EGR1) in the Bovine Corpus Luteum. Mol. Endocrinol. 2008, 22, 403-414. [CrossRef] [PubMed]

153. Kohli, G.; Clelland, E.; Peng, C. Potential targets of transforming growth factor-beta1 during inhibition of oocyte maturation in zebrafish. Reprod. Biol. Endocrinol. 2005, 3, 53. [CrossRef] [PubMed]

154. Ingman, W.V.; Robertson, S.A. Defining the actions of transforming growth factor beta in reproduction. BioEssays 2002, 24, 904-914. [CrossRef] [PubMed]

155. Gallicano, G.I. Composition, regulation, and function of the cytoskeleton in mammalian eggs and embryos. Front. Biosci. 2001, 6, d1089-d1108. [PubMed]

156. Albertini, D.F. Cytoplasmic microtubular dynamics and chromatin organization during mammalian oogenesis and oocyte maturation. Mutat. Res. Genet. Toxicol. 1992, 296, 57-68. [CrossRef]

157. Gregoraszczuk, E.L.; Słomczyńska, M. The cytoskeleton proteins and LH-regulated steroidogenesis of porcine luteal cells. Folia Histochem. Cytobiol. 1996, 34, 35-39.

158. Sewer, M.B.; Li, D. Regulation of steroid hormone biosynthesis by the cytoskeleton. Lipids 2008, 43, 1109-1115. [CrossRef] [PubMed]

159. Carnegie, J.A.; Tsang, B.K. The Cytoskeleton and Rat Granulosa Cell Steroidogenesis: Possible Involvement of Microtubules and Microfilaments1. Biol. Reprod. 1988, 38, 100-108. [CrossRef] [PubMed]

160. Xu, C.; Zhu, S.; Wu, M.; Han, W.; Yu, Y. Functional Receptors and Intracellular Signal Pathways of Midkine (MK) and Pleiotrophin (PTN). Biol. Pharm. Bull. 2014, 37, 511-520. [CrossRef] [PubMed]

161. Sastry, S.; Horwitz, A. Integrin cytoplasmic domains: Mediators of cytoskeletal linkages and extra- and intracellular initiated transmembrane signaling. Curr. Opin. Cell Biol. 1993, 5, 819-831. [CrossRef]

162. Delon, I.; Brown, N.H. Integrins and the actin cytoskeleton. Curr. Opin. Cell Biol. 2007, 19, 43-50. [CrossRef] [PubMed]

163. Matsuoka, Y.; Li, X.; Bennett, V. Adducin: Structure, function and regulation. Cell. Mol. Life Sci. 2000, 57, 884-895. [CrossRef] [PubMed]

164. Pariser, H.; Perez-Pinera, P.; Ezquerra, L.; Herradón, G.; Deuel, T.F. Pleiotrophin stimulates tyrosine phosphorylation of $\beta$-adducin through inactivation of the transmembrane receptor protein tyrosine phosphatase $\beta / \zeta$. Biochem. Biophys. Res. Commun. 2005, 335, 232-239. [CrossRef] [PubMed]

165. Gadde, S.; Heald, R. Mechanisms and Molecules of the Mitotic Spindle. Curr. Biol. 2004, 14, R797-R805. [CrossRef] [PubMed]

166. Sun, Q.-Y. Role of NuMA in vertebrate cells: Review of an intriguing multifunctional protein. Front. Biosci. 2006, 11, 1137. [CrossRef] [PubMed]

167. Schatten, H.; Sun, Q.-Y. Centrosome dynamics during mammalian oocyte maturation with a focus on meiotic spindle formation. Mol. Reprod. Dev. 2011, 78, 757-768. [CrossRef] [PubMed]

168. Chen, H.-C.; Chan, P.-C. Adducin-1 is essential for mitotic spindle assembly through its interaction with myosin-X. New Biotechnol. 2014, 31, S151. [CrossRef] 
169. Brieno-Enriquez, M.A.; Moak, S.L.; Holloway, J.K.; Cohen, P.E. NIMA-related kinase 1 (NEK1) regulates the localization and phosphorylation of $\alpha$-Adducin (ADD1) and Myosin X (MYO10) during meiosis. bioRxiv 2017. [CrossRef]

170. Terzaghi, L.; Luciano, A.M.; Modina, S.C.; Lodde, V. Role of progesterone receptor membrane component-1 in regulating bovine granulosa cells mitosis: A preliminary study. In Proceedings of the Annual Meeting of the Society for the Study of Reproduction, San Juan, XA, USA, 18-20 June 2015.

171. Terzaghi, L.; Tessaro, I.; Raucci, F.; Merico, V.; Mazzini, G.; Garagna, S.; Zuccotti, M.; Franciosi, F.; Lodde, V. PGRMC1 participates in late events of bovine granulosa cells mitosis and oocyte meiosis. Cell Cycle 2016, 15, 2019-2032. [CrossRef] [PubMed]

172. Vaheri, A.; Carpén, O.; Heiska, L.; Helander, T.S.; Jääskeläinen, J.; Majander-Nordenswan, P.; Sainio, M.; Timonen, T.; Turunen, O. The ezrin protein family: Membrane-cytoskeleton interactions and disease associations. Curr. Opin. Cell Biol. 1997, 9, 659-666. [CrossRef]

173. Sternlicht, H.; Farr, G.W.; Sternlicht, M.L.; Driscoll, J.K.; Willison, K.; Yaffe, M.B. The t-complex polypeptide 1 complex is a chaperonin for tubulin and actin in vivo. Proc. Natl. Acad. Sci. USA 1993, 90, 9422-9426. [CrossRef] [PubMed]

174. Brackley, K.I.; Grantham, J. Activities of the chaperonin containing TCP-1 (CCT): Implications for cell cycle progression and cytoskeletal organisation. Cell Stress Chaperones 2009, 14, 23-31. [CrossRef] [PubMed]

175. Cui, X.; Sun, Y.; Wang, X.; Yang, C.; Ju, Z.; Jiang, Q.; Zhang, Y.; Huang, J.; Zhong, J.; Yin, M. A g.-1256 A > C in the Promoter Region of CAPN1 is Associated with Semen Quality Traits. Reproduction 2016, 152, 101-109. [CrossRef] [PubMed]

176. Kawashima, I.; Liu, Z.; Mullany, L.K.; Mihara, T.; Richards, J.S.; Shimada, M. EGF-like factors induce expansion of the cumulus cell-oocyte complexes by activating calpain-mediated cell movement. Endocrinology 2012, 153, 3949-3959. [CrossRef] [PubMed]

177. Breitenecker, G.; Friedrich, F.; Kemeter, P. Further investigations on the maturation and degeneration of human ovarian follicles and their oocytes. Fertil. Steril. 1978, 29, 336-341. [CrossRef]

178. Hatta, T.; Tsuji, N.; Miyoshi, T.; Islam, M.K.; Alim, M.A.; Yamaji, K.; Anisuzzaman; Fujisaki, K. Leucine aminopeptidase, HILAP, from the ixodid tick Haemaphysalislongicornis, plays vital roles in the development of oocytes. Parasitol. Int. 2010, 59, 286-289. [CrossRef] [PubMed]

179. Patel, O.V.; Bettegowda, A.; Ireland, J.J.; Coussens, P.M.; Lonergan, P.; Smith, G.W. Functional genomics studies of oocyte competence: Evidence that reduced transcript abundance for follistatin is associated with poor developmental competence of bovine oocytes. Reproduction 2007, 133, 95-106. [CrossRef] [PubMed] 